\title{
Head-started Agassiz's desert tortoises Gopherus agassizii achieved high survival, growth, and body condition in natural field enclosures
}

\author{
Kenneth A. Nagy ${ }^{1, *}$, Brian T. Henen $^{2}$, L. Scott Hillard ${ }^{1}$ \\ ${ }^{1}$ Department of Ecology and Evolutionary Biology, University of California, Los Angeles, California 90095-1606, USA \\ ${ }^{2}$ Environmental Affairs, MAGTFTC MCAGCC, Twentynine Palms, California 92278, USA
}

\begin{abstract}
We measured survival, growth, and body condition of 8 hatchling cohorts of desert tortoises Gopherus agassizii (living in predator-resistant outdoor pens in the Mojave Desert, California, USA) over $11 \mathrm{yr}$ to evaluate head-starting methods. At $11 \mathrm{yr}$ of age, 7 times as many of the first cohort had survived than if they had been free-living tortoises. Subsequent improvements in predator control, food and water supplementation, and pen structure increased survival from 7 to 10 times that under wild conditions in younger cohorts. Annual survival averaged $96 \%$. Carapace length (CL) increased $6.95 \mathrm{~mm} \mathrm{yr}^{-1}$, similar to that of free-living tortoises. Annual growth rates varied with calendar year (possibly reflecting food and water supply), age, cohort (year hatched), mother, and in 4 dry years, with crowding. Most of the first cohort grew to a releasable size (CL $>100 \mathrm{~mm}$ ) by their 9th year. Body condition indices remained high, indicating little dehydration despite droughts in 8 of the 11 years, because irrigation offered drinking opportunities. Headstarted tortoises developed fully hardened shells ( $\geq 98 \%$ of adult shell hardness) earlier (10.1 vs. $11.6 \mathrm{yr})$, but at a larger CL (117 vs. $104 \mathrm{~mm})$ than did free-living tortoises. Selective feeding in head-start pens decreased subsequent germination of favored wildflower species, apparently by reducing the natural seedbank. Consequently, we reseeded and irrigated each autumn to promote subsequent spring food supply. We irrigated in early summer to enable drinking and ensuing consumption of dry, dead plants and Bermuda grass hay, a supplement. These procedures can greatly improve juvenile survivorship, and increase numbers of hard-shelled, midsized juveniles to help augment wild populations.
\end{abstract}

KEY WORDS: Survivorship · Predation · Emergence success · Density effects · Condition Index · Shell hardness index

\section{INTRODUCTION}

Head-starting is one means to augment populations of Agassiz's desert tortoise Gopherus agassizii, a threatened species (US Fish and Wildlife Service 1994, 2011a). Here, we quantified the effectiveness of headstart protocols evaluated on penned G. agassizii in the Mojave Desert of California, USA. Head-starting should increase survival of tortoise eggs and young by reducing or eliminating death due to predation and the physical environment (e.g. dehydration and starvation during droughts) and by fostering juvenile growth and resistance to these threats (Morafka 1994,

*Corresponding author: kennagy@biology.ucla.edu
Morafka et al. 1997, Nagy et al. 1997, McGovern 2019). A primary goal is to add older, larger juveniles, with higher survival probabilities, to wild populations to enhance reproduction rates of local females and improve population rates of natural increase. This goal is consistent with specific recovery guidance under the US Endangered Species Act (USFWS 1994, 2011a).

Desert tortoises have low egg and juvenile survivorship (Turner et al. 1986, 1987a, Karl 1999, Bjurlin \& Bissonette 2004), but have high adult survivorship and long lives (Turner et al. 1984, 1986, 1987a, Curtin et al. 2009), as do many chelonians (e.g. Wilbur \& Morin 1988, Congdon \& Gibbons 1990,

(1) The authors 2020. Open Access under Creative Commons by Attribution Licence. Use, distribution and reproduction are unrestricted. Authors and original publication must be credited. 
Kuchling 1999). But adult growth is slow, sexual maturity is reached late (ca. $12-20$ yr in female desert tortoises; Turner et al. 1987b, Germano 1994), and females have low fecundity (ca. 8 eggs $\mathrm{yr}^{-1}$; Turner et al. 1986, Mueller et al. 1998, Wallis et al. 1999, Lovich et al. 2015). These life-history traits predispose population vulnerability due to predation on eggs and young in areas experiencing unusually high predation. Recent studies have indicated that juvenile and adult mortality have increased and densities have declined in most Mojave Desert populations (Allison \& McLuckie 2018). Consequently, increasing young tortoise survival, such as provided by head-starting efforts, should increase recruitment and help wild populations recover.

We built predator-resistant enclosures in an area of high tortoise density (Woodman et al. 2001) and goodquality tortoise habitat (Barrows et al. 2016) containing creosote bush, white bursage, and galleta grass vegetation in the south-central Mojave Desert. The fenced enclosures with overhead netting excluded most terrestrial and avian predators. Initially, we kept living conditions as natural as possible for enclosed juvenile tortoises (i.e. native vegetation and substrate) to optimize their fitness after being released. However, subsequent droughts depleted native food supplies and threatened juvenile health and survivorship, so we supplemented food and water. The 2 main 'head-starting' factors we provided to juveniles were protection from predation and provision of adequate plant food and drinking water via a sprinkler irrigation system. We evaluated the effects of these relatively simple treatments on annual survivorship and growth while inside head-start enclosures and compared them to the age-specific survivorships and growth rates of free-living G. agassizii (Turner et al. 1987a,b, Medica et al. 2012, Nagy et al. 2015b). Additionally, we measured how shell hardness, which should convey resistance to predation by common ravens Corvus corax and other predators (Nagy et al. 2011), changed with body size and how shell hardness and growth were affected by irrigation.

\section{MATERIALS AND METHODS}

\subsection{Study site and weather}

In winter 2005-2006, we built 3 fenced enclosures, each a $30.8 \times 46.2 \mathrm{~m}$ rectangle enclosing natural Mojave
Desert vegetation, on a flat area in good desert tortoise habitat in the Sand Hill Range Training Area (hereafter Sand Hill) of the Marine Corps Air Ground Combat Center (MCAGCC), San Bernardino County, California. This head-start facility is known as the Tortoise Research And Captive Rearing Site (TRACRS). Fencing consisted of galvanized screen (122 cm wide) having $6 \mathrm{~mm}$ square mesh, buried $61 \mathrm{~cm}$ deep, extending $61 \mathrm{~cm}$ above ground, and connected to the bottom of the 1.22 or $1.52 \mathrm{~m}$ high section of $5.1 \mathrm{~cm}$ mesh cyclone fencing. The $6 \mathrm{~mm}$ mesh prevented entry by digging rodents, large snakes, and predatory lizards. A band of metal flashing $51 \mathrm{~cm}$ high was fastened to the top of the $6 \mathrm{~mm}$ mesh and secured to the cyclone fence to exclude climbing rodents. Large birds were excluded by overhead netting $(5.1 \mathrm{~cm}$ mesh). We constructed elevated threshold doors for human entry and to block small animal entry. Each enclosure was surrounded with a short fence of $25 \mathrm{~mm}$ poultry mesh, $30 \mathrm{~cm}$ tall and $0.6 \mathrm{~m}$ outside of the enclosure fence, to prevent potential contact of diseased wild tortoises with the head-start enclosure mesh. A bigger, fourth enclosure, $30.8 \times 92.4 \mathrm{~m}$, also containing natural vegetation, was built in 2008 with the same $5.1 \mathrm{~cm}$ mesh bird netting overhead, but with solid walls of corrugated metal sheeting that were $120 \mathrm{~cm}$ above ground and buried $60 \mathrm{~cm}$ (Fig. 1).

We subdivided 2 of the small enclosures into 24 pens, each $7.7 \times 7.7 \mathrm{~m}$, by partially burying $61 \mathrm{~cm}$ high metal sheeting. Similarly, we subdivided part of the larger, metal-walled enclosure into 24 pens $(7.7 \times$ $7.7 \mathrm{~m}$ ). These 72 small pens served both as private enclosures for gravid females to nest and lay their eggs during springs of 2006 through 2013 and as pens for the females' hatchlings during their first winter. This allowed us to identify the mother of every hatchling (Nagy et al. 2016). Subsequently, we
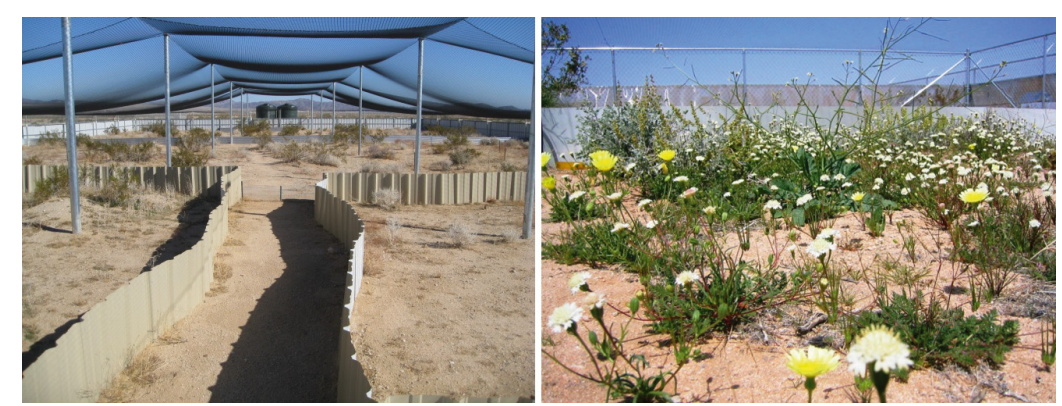

Fig. 1. A head-start enclosure (left) subdivided into small pens (foreground) and larger pens (background) at the Tortoise Research And Captive Rearing Site (TRACRS) on the Twentynine Palms Marine Base. Springtime annual wildflowers (right), including preferred food species (desert dandelion Malacothrix glabrata; yellow flowers and desert pincushion Chaenactis fremontii; white flowers) 
connected some $7.7 \times 7.7 \mathrm{~m}$ pens by removing small partition sections to form larger communal enclosures for entire juvenile year classes (or cohorts). We also moved some entire cohorts into larger, undivided enclosures. All enclosures used a sprinkler system to (1) supplement rainfall and (2) encourage plant germination and growth during drought years. Our rain gauges, placed within sprinkler footprints, measured an average of $12.7 \mathrm{~mm}$ (range: 5.1$22.4 \mathrm{~mm}$ ) of water $\mathrm{h}^{-1}$. When necessary, native fire ant colonies were controlled with ant-species-specific poison bait in tortoise-proof stations.

We used weather records from the nearby National Weather Service station, located approximately $10 \mathrm{~km}$ away and having similar elevation and topography (Nagy et al. 2016), to calculate long-term average annual rainfall. Because desert rains can be localized, we installed 3 rain gauges within TRACRS to obtain more accurate precipitation data. Annual rainfall data are reported as total precipitation measured between 1 October and 30 September (hereafter 'year') the following year.

\subsection{Mycoplasmosis status}

Prior to this study, upper respiratory tract disease (URTD), and specifically mycoplasmosis, was present in some tortoises at Sand Hill, so we used aseptic handling techniques (US Fish and Wildlife Service 2009). We examined female tortoises for clinical signs of URTD and took blood samples to quantify antibodies to Mycoplasma agassizii and M. testudineum (Christopher et al. 1999, US Fish and Wildlife Service 2011b). Adult plasma was analyzed for M. agassizii from 2006-2015, except 2014, and for M. testudineum in 2012 and 2013. Juvenile plasma was analyzed for $M$. agassizii in 2007, 2008, and 2009. Any juvenile that may have been exposed to Mycoplasma was quarantined until it was determined to be free of clinical sign and of antibodies to Mycoplasma spp. (via enzyme-linked immunosorbent assay [ELISA] tests; Brown et al. 1999, Christopher et al. 2003). All juveniles hatched at TRACRS had negative ELISA results for M. agassizii and were subsequently moved to experimental enclosures.

\subsection{Food availability and food supplementation}

We measured food availability as plant cover to avoid harming the food supply to our tortoises. In mid-April of 2006-2018, we measured annual plant cover $(0-100 \%)$ of combined native and exotic species growing in one of our enclosures. We used a $1 \mathrm{~m}^{2}$ Daubenmire square of gridded PVC pipe (100 squares, each $0.01 \mathrm{~m}^{2}$ ) using fishing line cross-strung at $10 \mathrm{~cm}$ intervals. In each of the 24 pens, we placed the square within the irrigation spray zone and then outside the spray zone, with placement judged to capture the representative cover in both zones. For each year, we calculated average annual plant cover as (1) the sum of \% cover for all annuals in each $\mathrm{m}^{2}$ plot ( $\mathrm{n}=48),(2)$ the mean of dry (not irrigated) and wet (irrigated) $\%$ cover for each $7.7 \times 7.7$ pen $(n=24$ each), and (3) as the mean \% cover for all 24 pens. We also measured species richness as the number of forb species in each $\mathrm{m}^{2}$ plot and total numbers of herb species (i.e. forbs and grasses) in the enclosure (sum of all species in the 48 Daubenmire plots). Due to drought-induced shortages of herbs in spring of 2007, 2012, and 2013, we provided potted, nurserygrown plants (African daisies Osteospermum spp. and Bermuda grass Cynodon dactylon) to enclosures as needed. At the end of those seasons, we removed the potted remains. Beginning in 2012, we sowed seeds of native forbs (Malacothrix glabrata, Chaenactis fremontii, Plantago insularis, and Salvia columbariae) every autumn to replenish the soil seed bank with food species. Beginning in summer 2013, we added dry Bermuda grass hay to all occupied enclosures to supplement the dry herbs that tortoises were eating. Head-start tortoises ate each of these species.

\subsection{Egg procurement}

Each spring from 2006 through 2016, we radiotracked wild adult female tortoises (transmitter model AI-2, Holohil Systems) that lived within $5 \mathrm{~km}$ of the head-start facility and used some ELISA-negative females as egg donors inside TRACRS. We examined females for oviducal eggs (via palpation and primarily by x-ray radiography; MinXray Portable models HF8015 and X750G; Gibbons \& Greene 1979, Wallis et al. 1999). When a female's radiograph showed moderately to heavily shelled (calcified) eggs, we transferred her to an individual TRACRS pen to oviposit. We provided each female at least 2 burrows to use as refugia or for nesting. Some females dug additional burrows. We avoided close monitoring of females to avoid influencing when and where they nested, and we did not search burrows for nests to avoid disrupting or altering egg placement and nest conditions. Both of these factors may influence incubation temperatures, potentially altering hatchling 
sex ratios (see Nagy et al. 2016 and references therein) and nest success. Females oviposited after 1-4 wk at TRACRS, were offered water to drink, and were released to their home burrow. Radiography confirmed that many egg-donor females produced second clutches after being released.

\subsection{Nest and egg success}

We recorded hatchling emergence events for each nest laid, and we uniquely marked emerging hatchlings on vertebral scutes with a permanent marking pen (Sharpie) and a small printed label epoxied to one scute. Emergence success was calculated as number of hatchlings emerging out of the number of eggs laid (typically equaling clutch size from radiographs). We compared our emergence success measurements with the life table value in Turner et al. (1987a) for free-living tortoises at Goffs, California.

\subsection{Juvenile survivorship}

We captured most juveniles twice each year, in spring (late March, early April) and in autumn (late August, early September), to measure survival and growth. Despite extensive search efforts, if we repeatedly failed to detect individuals, we assumed they died shortly after they were last seen alive. Annual survivorship calculations were based only on those juveniles confirmed visually to be alive or dead (or repeatedly missing and assumed dead) 1 yr later, and were compared to age-specific survivorship estimates for free-living juveniles (Turner et al. 1987a, Bjurlin \& Bissonette 2004).

\subsection{Growth measurements and analyses}

We measured body mass to $0.1 \mathrm{~g}$ using portable digital scales and standardized orthogonal, straightline shell dimensions to $0.1 \mathrm{~mm}$ with digital calipers (Nagy et al. 2002). These included carapace length $\left(\mathrm{CL}_{i}\right.$ the distal measure at nuchal and supracaudal scute notches), shell width (SW; the distal measure at notches between left and right marginal scutes 5 and $6)$, and shell height $\left(\mathrm{SH}_{i}\right.$ the distal, vertical measure of plastral and carapacial scutes measured perpendicular to the SW measure). We based growth measurements on shell lengths rather than body masses, which can vary widely due to differences in hydra- tion, reproductive mass, and gut fill rather than somatic growth (Nagy \& Medica 1986, Jacobson et al. 1993, Henen 1997, Nagy et al. 2002). We analyzed growth rates as annual changes in $\mathrm{CL}$, tested these for effects of age, year, cohort, mother, and individuals, and we compared annual growth rates with those of juveniles in 3 wild populations (see Section 3.4 below for details).

\subsection{Biomass density effects on growth rate}

We used linear least-squares regression (using SPSS - Statistical Package for the Social Sciences) and ANCOVA (Zar 1999) to evaluate relationships

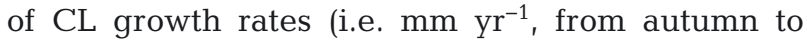
autumn) to tortoise biomass density (= biodensity: $\mathrm{g}$ tortoise $\mathrm{m}^{-2}$ ground surface) among pens. First, we estimated growth rates as the mean increase in CL $\mathrm{yr}^{-1}$ for 19-37 pens $\mathrm{yr}^{-1}$, with a minimum of 3 ind. pen $^{-1}$. We estimated each pen's biodensity as the sum of autumn body masses at the beginning of the $12 \mathrm{mo}$, of all individuals in that pen, divided by ground surface area of that pen.

\subsection{Body condition and shell hardness indices}

We calculated body condition index (BCI) as the ratio of body mass $(\mathrm{g})$ to shell volume $\left(\mathrm{cm}^{3}\right)$ estimated as the product of standardized CL, width, and height (in cm; Nagy et al. 2002). For juveniles, this index varies primarily with hydration state and gut fill. We analyzed autumn BCI (late August, early September) of all juveniles each year, as growth rates were greatest in spring, which is when body mass fluctuates considerably. BCIs reflect dehydration or atrophy (BCI $\ll 0.45)$, healthy or normal hydration and nutrition $(0.45-0.60)$, and prime body condition $(>0.60$; Nagy et al. 2002).

We measured shell compressibility using a tensioncalibrated digital micrometer placed vertically at the middle of a juvenile's carapace and plastron, typically at the third vertebral scute (Nagy et al. 2011). Then we calculated shell hardness index (SHI) as 100 $\times(\mathrm{CSH} / \mathrm{USH})$, where CSH and USH are compressed and uncompressed shell height $(0.01 \mathrm{~mm})$, respectively. Adult shells are incompressible $(\mathrm{SHI}=100 \%)$ at the pre-set tension of the micrometer. We compared the age and size at which juveniles headstarted with irrigation reached adult SHI with those of juveniles head-started without irrigation (Nagy et al. 2011). 


\subsection{Statistics}

Results are indicated as mean \pm SD and sample size (n). Differences between means were evaluated using 2-tailed Student's $t$-tests and 1- or 2-way ANOVA, considering probability values $p<0.05$ statistically significant. We used least-squares linear regression to evaluate relationships between annual growth rates and plant cover as an index of annual food supply, precipitation (rain plus irrigation) as an index of annual water supply, and pen-specific tortoise mass (biodensity) as an index of annual food demand. We used general linear model (GLM) ANOVAs to evaluate main effects of year, age, cohort, and mother on growth rates, and nested (or hierarchical) ANOVAs to evaluate age, cohort, and mother effects, nested with effects of year because the data set was not crossed (Zar 1999). A 1way repeated measure ANOVA (1WRMA) provided the same main and post hoc results as 1-way ANOVA with mother as a random factor.

To compare regression slopes and elevations, we used ANCOVA (Zar 1999). We used non-linear, leastsquares analyses (SigmaPlot v.11) to analyze fit for curvilinear relationships (e.g. exponential rise to asymptotes), and Spearman rank order correlations $\left(\mathrm{r}_{\mathrm{S}}\right)$ for other non-linear, heteroscedastic and nonnormal data. We used $Z$-tests to compare regression correlation coefficients $\left(\mathrm{r}^{2}\right.$; Zar 1999).

Juvenile shells harden asymptotically to adult values (Nagy et al. 2011), so the difference between juvenile and adult SHI (the same as compressibility) converges asymptotically on zero as juveniles grow. Logarithmic transform of this convergence results in linear relationships to tortoise age (years) and size (CL), enabling us to estimate the age and size at which juvenile shells reach 98 and $99 \%$ of adult SHI. We also used ANCOVA to compare SHI-to-CL regressions and SHIto-age regressions, to evaluate their shell hardening trajectories to those of head-started tortoises experiencing only natural rainfall (Nagy et al. 2011). If slopes were similar among groups, we compared their elevations (at $\mathrm{p}<$ 0.05 ; Zar 1999). If 2 regression slopes differed significantly ( $t$-test with $\mathrm{p}<$ 0.05 ), we used a Zerbe test (Zerbe et al. 1982, Loehr et al. 2006) to determine at which covariate values (CL or age) the 2 groups differed in elevation. We used the same procedures to test for growth rate differences among sites.

\section{RESULTS}

\subsection{Rainfall, irrigation, and plant cover}

Annual rainfall during this 2006-2017 study averaged $5.76 \mathrm{~cm}, 56 \%$ of the average $(10.2 \mathrm{~cm}$; Fig. 2$)$ during the previous $30 \mathrm{yr}$. However, rainfall varied considerably immediately before (2004-2005 at $189 \%$ and $2005-2006$ at $175 \%$ of average) and during this study (2006-2017; 8-117\% of average). There was a 4 yr (2007 through 2010) and a 5 yr (2012 through 2016) drought during our study (Fig. 2). Early in the study, we irrigated only when existing or anticipated drought conditions threatened the good germination and growth of herbs that tortoises eat. Later, we also irrigated in late spring and late autumn of most years to provide drinking opportunities. More frequent irrigation was needed beginning in 2012, the start of the 5 yr drought (Fig. 2).

Annual plant cover varied from $<1$ to $>36 \%$, and forb species richness varied from 2-19 species (Table 1). In 2012-2013, irrigation after January did not stimulate new germination.

\subsection{Emergence success}

Females laid 897 eggs in TRACRS during the first 8 laying seasons, spring 2006-2013. Emergence success ranged from $68-83 \% \mathrm{yr}^{-1}$ and averaged $73.8 \pm$ $5.2 \%(\mathrm{n}=8$; Table 2$)$. Annual emergence success was not correlated with rainfall, irrigation amounts, or average air temperature during mid-incubation (all $\mathrm{p}>0.39$ ). Our head-start process improved emergence success $(73.8 \pm 5.2 \%, \mathrm{n}=8)$ compared to those in wild conditions at Goffs, California $\left(55.2 \% ; t_{7}=\right.$

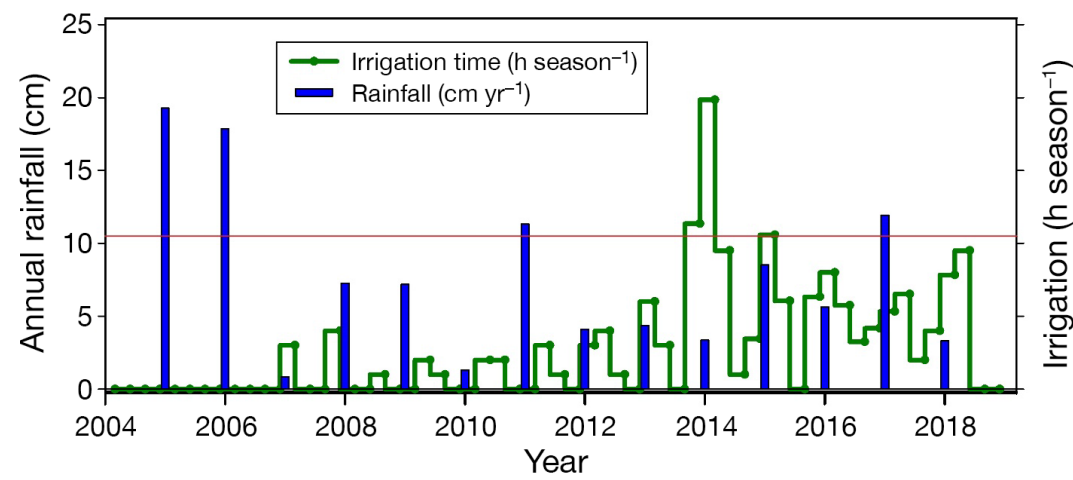

Fig. 2. Yearly rainfall (1 October to 30 September) measured at TRACRS (blue columns), 30 yr average annual rainfall nearby (Expeditionary Air Field; red horizontal line), and hours of irrigation per 3 mo season (green columns) from July 2004 to mid-2018. One hour of irrigation provided a $12.7 \mathrm{~mm}$ (ca. $0.5 \mathrm{inch}$ ) equivalent of 'rainfall' 
Table 1. Annual plant cover (\%) in 24 individual $59.3 \mathrm{~m}^{2}$ pens at the Tortoise Research and Captive Rearing Site (TRACRS) head-start facility located at the Marine Corps Air Ground Combat Center, Twentynine Palms, California. Forb species richness is indicated for the entire enclosure (number of species per $1423 \mathrm{~m}^{2}$ )

\begin{tabular}{|lccccccccccc|}
\hline Cover & 2007 & 2008 & 2009 & 2010 & 2011 & 2012 & 2013 & 2014 & 2015 & 2016 & 2017 \\
\hline Mean & 3.63 & 11.91 & 9.56 & 11.76 & 9.38 & 2.05 & 0.94 & 8.08 & 22.10 & 36.90 & 24.44 \\
SD & 2.55 & 4.26 & 4.53 & 8.55 & 4.57 & 4.57 & $\begin{array}{c}0.84 \\
9\end{array}$ & $\begin{array}{c}8.22 \\
16\end{array}$ & $\begin{array}{c}8.16 \\
15\end{array}$ & $\begin{array}{c}18.57 \\
10\end{array}$ & $\begin{array}{c}11.98 \\
12\end{array}$ \\
Forbs & 10 & 19 & 14 & 19 & 17 & 2 & 9 & &
\end{tabular}

Table 2. Emergence success (\% of eggs laid with hatchlings emerging from nests) and annual survivorship (\%) by age of 8 cohorts of juvenile Agassiz's desert tortoises raised in the TRACRS facility. Numbers of eggs obtained per year were 166, 48, 146, 187, 110, 112, 87, and 41 from 2006-2013 (lower numbers during drought years)

\begin{tabular}{|c|c|c|c|c|c|c|c|c|c|c|c|c|c|c|c|}
\hline \multirow[t]{2}{*}{ Cohort } & \multirow{2}{*}{ Emergence } & & & & & & \multicolumn{6}{|c|}{ Age (yr) } & \multirow[t]{2}{*}{ Mean } & \multirow[t]{2}{*}{$\mathrm{SD}$} & \multirow[t]{2}{*}{$\mathrm{n}$} \\
\hline & & 1 & 2 & 3 & 4 & 5 & 6 & 7 & 8 & 9 & 10 & 11 & & & \\
\hline 2006 & 75.3 & 88.8 & 86.5 & 97.9 & 86.2 & 96.3 & 100.0 & 92.3 & 97.2 & 98.6 & 94.9 & 95.2 & 94.0 & 4.9 & 11 \\
\hline 2007 & 83.3 & 95.0 & 97.4 & 89.2 & 100.0 & 100.0 & 100.0 & 97.0 & 100.0 & 100.0 & 100.0 & & 97.9 & 3.5 & 10 \\
\hline 2008 & 69.9 & 100.0 & 83.3 & 96.5 & 98.8 & 100.0 & 96.3 & 100.0 & 98.2 & 98.2 & & & 96.8 & 5.3 & 9 \\
\hline 2009 & 67.9 & 87.4 & 66.7 & 95.9 & 97.2 & 98.6 & 100.0 & 98.5 & 100.0 & & & & 93.0 & 11.4 & 8 \\
\hline 2010 & 76.4 & 85.7 & 93.1 & 100.0 & 97.0 & 100.0 & 95.4 & 100.0 & & & & & 95.9 & 5.2 & 7 \\
\hline 2011 & 74.1 & 95.2 & 100.0 & 93.7 & 100.0 & 98.6 & 100.0 & & & & & & 97.9 & 2.8 & 6 \\
\hline 2012 & 67.8 & 100.0 & 94.9 & 100.0 & 100.0 & 100.0 & & & & & & & 99.0 & 2.3 & 5 \\
\hline 2013 & 75.6 & 96.8 & 86.7 & 100.0 & 96.2 & & & & & & & & 94.9 & 5.7 & 4 \\
\hline Mean & 73.8 & 93.6 & 88.6 & 96.7 & 96.9 & 99.1 & 98.6 & 97.6 & 98.9 & 98.9 & 97.5 & & 96.0 & & \\
\hline $\mathrm{SD}$ & 5.2 & 5.6 & 10.6 & 3.8 & 4.6 & 1.4 & 2.2 & 3.2 & 1.4 & 0.9 & 3.6 & & 5.9 & & \\
\hline $\mathrm{n}$ & 8 & 8 & 8 & 8 & 8 & 7 & 6 & 5 & 4 & 3 & 2 & & 8 & & \\
\hline
\end{tabular}

10.15, $\mathrm{p}=10^{-5}$ ). With one exception (see Section 3.3 below), vertebrate predators apparently did not enter the enclosures. In regular inspections of nesting pens and burrows, we saw no nest disturbance or egg predation by vertebrates or invertebrates, including fire ants Solenopsis xyloni or other ant species, and no indirect evidence of predation (e.g. broken eggshells, dead embryos, digging, or footprints).

\subsection{Juvenile survival}

Juvenile survivorship inside TRACRS was high, averaging $96.0 \% \mathrm{yr}^{-1}$ overall (Table 2). Average annual survivorship was not correlated with age $\left(\mathrm{r}_{\mathrm{S}}=\right.$ $0.427, \mathrm{p}=0.198, \mathrm{n}=11$ ). Survivorship was low $(66.7 \%)$ in the 2009 cohort during the 2010-2011 period, as a result of a predation event (see below). Annual survival was nearly $100 \%$ in the latter years (2014-2017). For the 3 oldest cohorts, survival to $9 \mathrm{yr}$ - the age when about half of the surviving individuals were large enough to release-was 48.6 juveniles per 100 eggs laid. As of autumn 2017, among all cohorts combined there were 50 live juveniles per 100 eggs laid.
We were able to determine causes of death for some juveniles. If carcasses were not found, absences from spring and autumn censuses indicated the tortoise died underground during winter. Inspection of the few smaller juvenile carcasses we found implicated death by ants and beetles attacking the exposed yolk sac and umbilicus, or soft, moist, or incompletely closed umbilical scar. Additionally, older juveniles that were overturned or trapped in vegetation or fencing likely overheated in the sun and died. We detected no dead juveniles that may have frozen after emerging to drink winter rain. The lowest annual survivorship (66.7\%; Table 2) occurred in the 2009 cohort during 2010-2011, probably from avian predation. In autumn 2010, overhead netting in their enclosure failed along seams stitched with non-UV-resistant twine, opening large holes. The gaps allowed several days' access to a roadrunner Geoсоссух californianus, a burrowing owl Athene cunicularia, and probably common ravens Corvus corax, before we detected and closed the openings. Subsequently, we found several depredated carcasses of mostly 2009 juveniles and some 2010 cohort juveniles; several carcasses indicated signs of raven predation. We found the carcass of the 
roadrunner, which presumably could not escape, and we caught and released the owl unharmed. Additionally, horizontal support bars unique to the corrugated metal walls of Enclosure 4 were near ground level, and trapped small tortoises between the bar and wall or under the bar. Some of these tortoises died of thermal exposure. We suspect these structures also contributed to the death of tortoises we found upside down near these bars. Following the removal of these bars and continual netting inspection and repair efforts, mortality rates stabilized at very low levels in this enclosure.

\subsection{Annual growth rates}

The mean of all annual growth rates was $6.95 \pm$ $3.55 \mathrm{~mm} \mathrm{yr}^{-1}(\mathrm{n}=3361)$. Annual growth rates of the 8 hatchling cohorts averaged from 1.25-12.92 $\mathrm{mm} \mathrm{yr}^{-1}$ (Table S1 in the Supplement at www.int-res.com/ articles/suppl/n043p305_supp.pdf). Individual growth rates were more variable, ranging from $-2.4 \mathrm{~mm} \mathrm{yr}^{-1}$ (a shrinking shell) to more than $+20 \mathrm{~mm} \mathrm{yr}^{-1}$. Even growth rates among clutch mates varied considerably. For example, growth rates of 5 clutch siblings living together during the 2006-2007 year varied from 1.23$12.04 \mathrm{~mm} \mathrm{yr}^{-1}$ (mean: $6.71 \pm 4.21 \mathrm{~mm}$ $\left.\mathrm{yr}^{-1}\right)$.

GLM ANOVAs documented the main effects of year, age, annual cohort, and mother (Table 3). The GLM ANOVA also matched univariate ANOVA test strengths and post hoc tests that identified means significantly different from others (Student-Newman-Keuls [SNK] test, all $\mathrm{p}<0.05$ ). There were many differences among years (e.g. low in 2013, high in 2017; Fig. 3), ages (mean growth rate correlated with age; Fig. 4), and cohorts (low in the 2011 cohort, high in the 2013 cohort; Fig. 5). Nested ANOVA confirmed the strength of year, age, cohort, and mother on growth rates (Table 3). The 1WRMAs were balanced and complete for 2 separate analyses, year and age. The 1WRMA detected a very strong effect of year $\left(F_{10,2769}=\right.$ $\left.219.55, \mathrm{p}<10^{-30}\right)$ and age $\left(F_{10,2769}=\right.$ $\left.123.59, \mathrm{p}<10^{-30}\right)$, with post hoc results nearly identical to those of the 1-way ANOVA. The 1WRMA also quantified
Table 3. General linear model with main effect of year, age, cohort (year hatched), and mother on 3361 annual growth rates $\left(\mathrm{mm} \mathrm{yr}^{-1}\right)$ measured over 11 yr for 8 cohorts of juvenile Agassiz's desert tortoises in the TRACRS head-start facility. Main effect could not analyze interactions. Nested ANOVA used variables age, cohort, and mother nested within year (e.g. mother-year indicates mother nested with year); $\mathrm{df}_{1}$ and $\mathrm{df}_{2}$ : degrees of freedom. All $\mathrm{p}<10^{-30}$ except for the simple nesting of mother within year (Mother-year* $\mathrm{p}<10^{-15}$ ). Other forms (e.g. age, cohort, and mother simultaneously nested within year) were incomplete, unbalanced designs

\begin{tabular}{|lccc|}
\hline & $F$ & $\mathrm{df}_{1}$ & $\mathrm{df}_{2}$ \\
\hline Main effect & & & \\
Year & 148.09 & 10 & 3284 \\
Age & 75.01 & 10 & 3284 \\
Cohort & 16.16 & 7 & 3284 \\
Mother & 4.34 & 49 & 3284 \\
Nested & & & \\
Year & 7.44 & 406 & 2905 \\
Mother-year* & 3.65 & 49 & 2905 \\
Year & 140.48 & 10 & 2856 \\
Cohort-year & 17.56 & 49 & 2856 \\
Mother-year & 1.75 & 445 & 2856 \\
Year & 140.48 & 10 & 2856 \\
Age-year & 17.57 & 49 & 2856 \\
Mother-year & 1.75 & 445 & 2856 \\
\hline
\end{tabular}

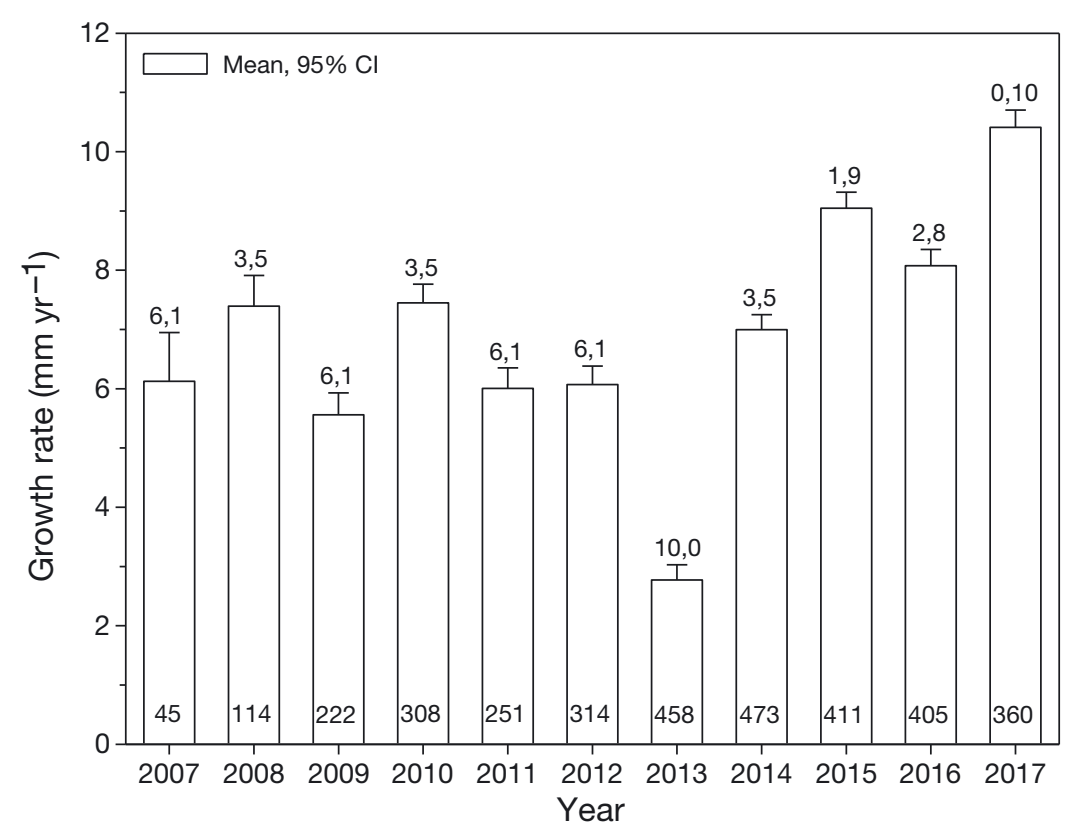

Fig. 3. Yearly variation in annual growth rates of juvenile head-started Agassiz's desert tortoises $\left(F_{10,3350}=197.21, \mathrm{p}<10^{-30}\right)$ at the TRACRS head-start facility. Annual growth was measured from October through September, matching the rainfall year and the first year of growth of hatchlings. Numbers separated by commas at the upper $95 \%$ confidence limit indicate the number of means higher and lower than it (e.g. 2013 had 10 means higher and zero means lower) by Student-Newman-Keuls post hoc comparisons $(p<0.05)$. Sample sizes indicated within bars. Effects of individual and year were very strong (2-way ANOVA, $F_{581,2769}=1.884, \mathrm{p}<10^{-15} ; F_{10,2769}=219.6, \mathrm{p}<10^{-30}$, respectively), but the factorial analysis design was incomplete, preventing tests of interactions 


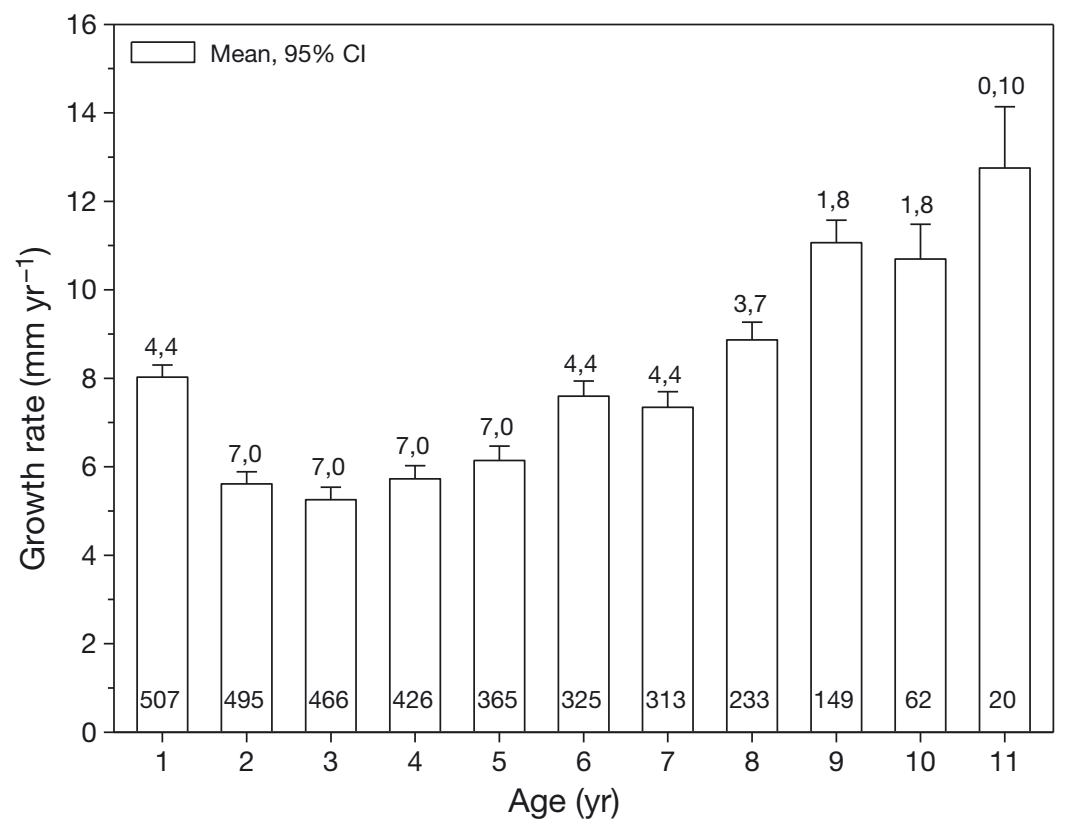

Fig. 4. Age variation in annual growth rate (GR) of juvenile Agassiz's desert tortoises $\left(1\right.$-way ANOVA, $\left.F_{10,3350}=88.14, \mathrm{p}<10^{-30}\right)$ at the TRACRS head-start facility. Age is indicated relative to hatching (September). Numbers separated by commas at the upper $95 \%$ confidence limit indicate the number of means higher and lower than it (e.g. $11 \mathrm{yr}$ old had zero means higher and 10 means lower) by Student-Newman-Keuls post hoc comparisons $(\mathrm{p}<0.05)$. Sample sizes indicated within bars. Mean growth rates correlated with age (with first year: $F_{1,9}=20.192$, $\mathrm{p}=0.001503 ; \mathrm{r}^{2}=0.6917 ; \mathrm{GR}=4.340+0.6263 \times$ year $;$ and without first year: $F_{1,8}=$ $82.82, \mathrm{p}=0.000017, \mathrm{r}^{2}=0.9119 ; \mathrm{GR}=2.707+0.8303 \times$ year $)$. ANCOVA found no difference between the 2 regressions $\left(\mathrm{p}>0.3\right.$ for slopes $t_{17}=1.1616$ and $\mathrm{p}>0.5$ for elevations $t_{18}=0.6552$ )

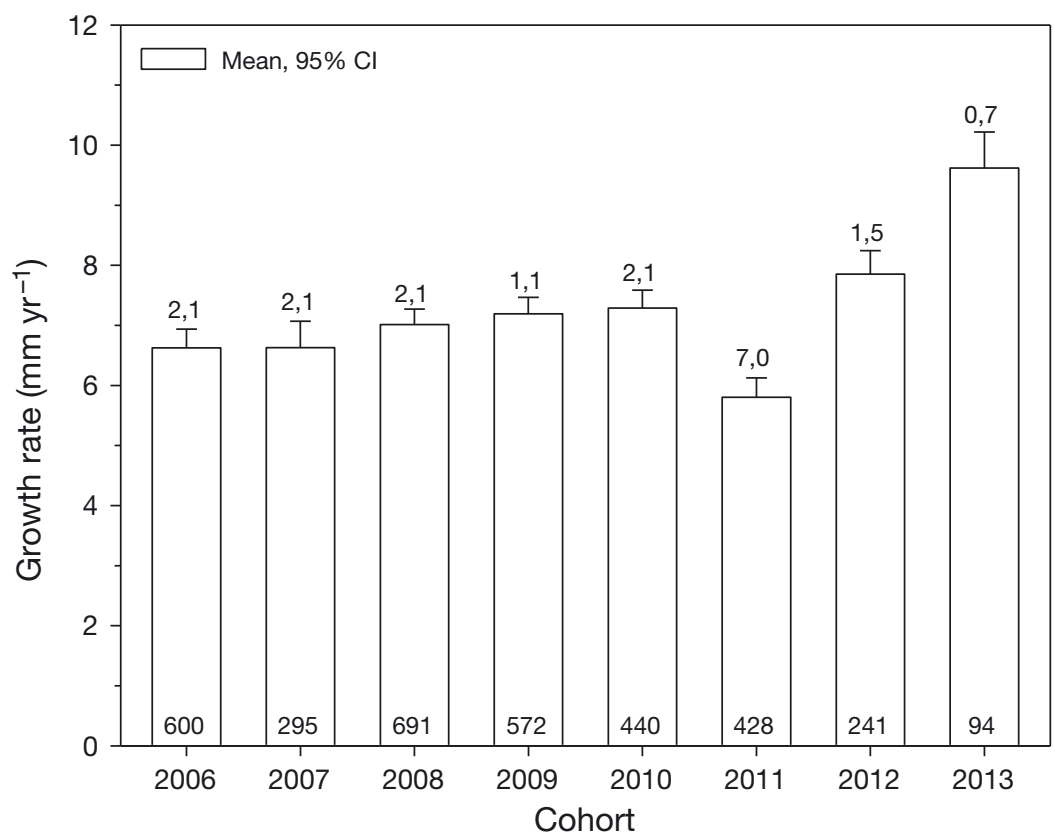

Fig. 5. Cohort variation in annual growth rates of juvenile Agassiz's desert tortoises $\left(1\right.$-way ANOVA $F_{7,3353}=18.98, \mathrm{p}<10^{-30}$ ) at the TRACRS head-start facility. Cohort refers to the year of hatching. Numbers separated by commas at the upper $95 \%$ confidence limit indicate the number of means higher and lower than it (e.g. cohort 2011 had 7 means higher and zero means lower) by Student-Newman-

Keuls post hoc comparisons $(\mathrm{p}<0.05)$. Sample sizes indicated within bars the strength of individuals $\left(F_{581,2769}=\right.$ $\left.1.8841, \mathrm{p}<10^{-30}\right)$. Simple linear regressions indicated that mean annual growth rates (Fig. 3) were correlated with annual plant cover (Table $1 ; F_{1,9}=$ 10.7081, $\mathrm{p}=0.0096, \mathrm{r}^{2}=0.5433$ ) and precipitation ( $=$ rain plus irrigation; $F_{1,9}=$ 5.728, $\mathrm{p}=0.04034, \mathrm{r}^{2}=0.3889$ ), suggesting growth is more closely associated with food availability than water availability. However, these 2 regression coefficients $\left(\mathrm{r}^{2}\right)$ were not different $\left(Z_{0.05,2}=0.4264, p=0.3349\right)$. Similarly, nonlinear regressions, with growth rates increasing exponentially to an asymptote, were moderately strong for annual plant cover (Fig. 6) and essentially nonexistent for precipitation $\left(F_{1,9}=0.1372, \mathrm{p}=0.7197, \mathrm{r}^{2}=0.0150\right)$; the 2 regression coefficients differed at $\mathrm{p}=0.0509\left(Z_{0.05,2}=1.6359\right)$.

The 1-way ANOVA indicated a strong maternal effect $\left(F_{49,3311}=2.510\right.$, $\mathrm{p}<10^{-8}$ ) among the 50 mothers, but the $\mathrm{p}$-value was larger than those for other univariate ANOVA $\left(\mathrm{p}<10^{-30}\right)$. Also, the offspring of only 5 mothers had significantly low $(\mathrm{n}=1$ ) or high $(\mathrm{n}=4)$ means in SNK post hoc tests. The one mother's group with low growth rates (mean: $5.01 \pm 0.350, \mathrm{n}=$ 18) represented $6 \mathrm{yr}$ of data for 3 hatchings of 2011, which had the lowest rates of all cohorts (Fig. 5), occurred during the early, slow growth ages (Fig. 4), and hatched at the beginning of a 5 yr drought. The 3 mothers with high offspring growth rates (20 hatchlings, weighted mean: $8.87 \pm 6.058, \mathrm{n}=$ 83) had hatchlings in only 2012 or 2013 or in 2012 and 2013, both years occurring after the slowest-growing cohort (2011) and included a combination of years with the highest growth rates (2014-2017; Fig. 3). The 4 offspring of female 35 had high growth rates (mean: $8.59 \pm 3.503, \mathrm{n}=32$ ), hatched in 2008 (a moderate cohort year; Fig. 5), started growing before the 5 yr drought, experienced improved irrigation and forage conditions (e.g. 2013-2016), and included an age effect (older tortoises, Fig. 4). 


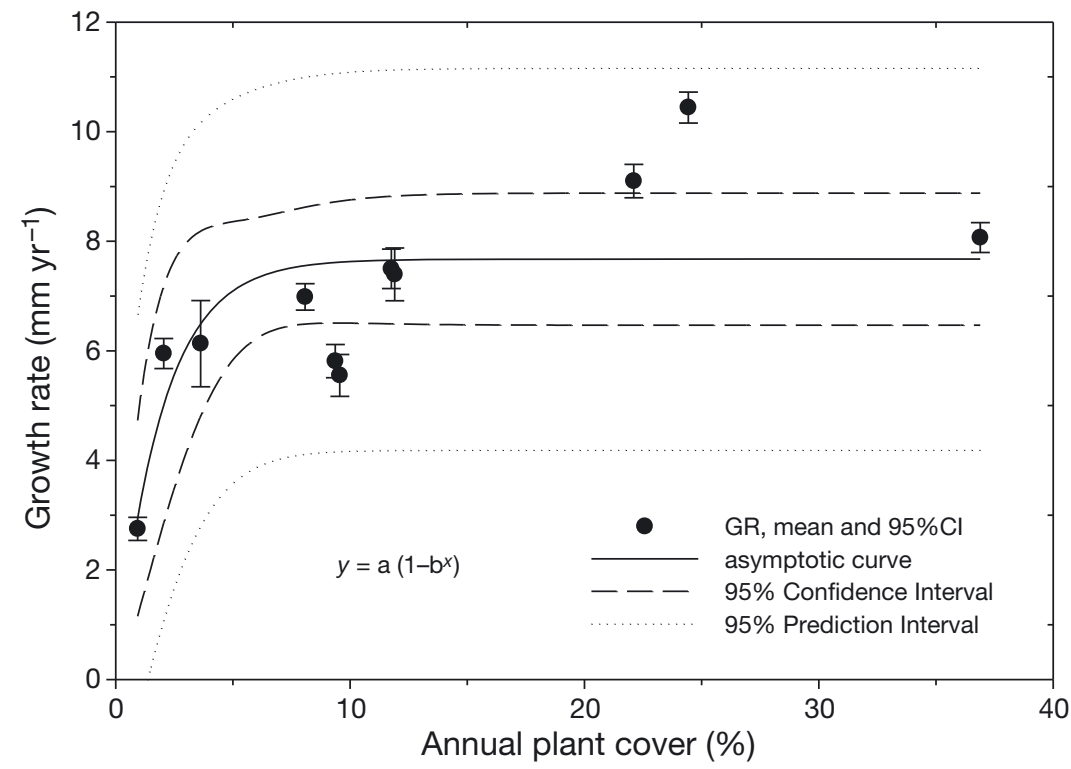

Fig. 6. Mean $\pm 95 \% \mathrm{CI})$ of annual growth rates $\left(\mathrm{GR}, \mathrm{mm} \mathrm{yr}^{-1}\right)$ of head-started Agassiz's desert tortoises each year in relationship to annual plant cover (\%) inside the enclosure that year, for $11 \mathrm{yr}$. The nonlinear curve $(y=7.674 \times[1-$ $\left.0.597^{x}\right] ; F_{1,9}=10.62, \mathrm{p}=0.00986, \mathrm{R}^{2}=0.5413$ ) was asymptotic (solid line) and

bound by $95 \%$ CI (dashed lines) and prediction intervals (dotted lines)

To compare growth rates (mm CL $\mathrm{yr}^{-1}$ ) of 3 freeliving Mojave Desert populations and 2 head-start populations, including TRACRS' head-start population, we evaluated the slopes of linear regressions relating CL to age (up to $11 \mathrm{yr}$; Fig. 7). The regression-based growth rates used annual mean CL measurements of estimated-age wild tortoises near Goffs, California (Turner et al. 1987a), known-age wild

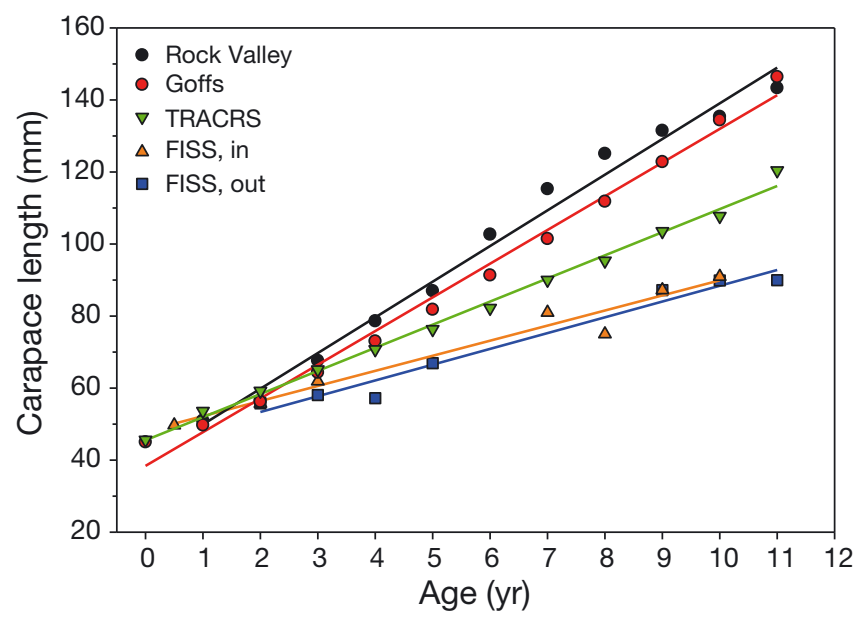

Fig. 7. Relationship of carapace length (CL) to age of knownage Agassiz's desert tortoises in 4 Mojave Desert populations. Least-squares regression equations were: $\mathrm{CL}=40.0+$ $9.91 \times$ age for Rock Valley; $C L=38.4+9.36 \times$ age for Goffs; $\mathrm{CL}=45.5+6.41 \times$ age for TRACRS; $\mathrm{CL}=48.0+4.19 \times$ age for Fort Irwin Study Site (FISS) enclosed in pens; and CL = $44.6+4.38 \times$ age for FISS free-ranging tortoises (out) juveniles in Rock Valley, Nevada (Turner et al. 1987b, Medica et al. 2012), known-age wild and head-started tortoises at Fort Irwin, California (Nagy et al. 2015b, L. S. Hillard \& M. W. Tuma unpubl. data), and known-age head-started juveniles at TRACRS. Growth rates were highest at Rock Valley and Goffs (estimated as the slopes of the regressions at 9.91 and $9.36 \mathrm{~mm}$ $\mathrm{yr}^{-1}$, respectively) and did not differ statistically from each other (ANCOVA, $\left.t_{19}=1.131, \mathrm{p}>0.13\right)$. Growth rates were lowest at Fort Irwin (enclosed: $4.19 \mathrm{~mm} \mathrm{yr}^{-1}$; free-ranging: $4.38 \mathrm{~mm}$ $\mathrm{yr}^{-1}$ ) and did not differ from each other (ANCOVA, $t_{10}=0.363, \mathrm{p}>0.36$ ). The growth rate via regression slope of TRACRS juveniles during their first $11 \mathrm{yr}\left(6.41 \mathrm{~mm} \mathrm{yr}^{-1}\right)$ was lower than those at Rock Valley and Goffs (both ANCOVA, $t>8.7, \mathrm{p}<0.000001, \mathrm{df}=$ 19 and 20, respectively), and higher than those at Fort Irwin (head-started ANCOVA, $t_{15}=6.41, \mathrm{p}<10^{-5}$; free-ranging $t_{15}=6.12$, $\mathrm{p}<1 \times 10^{-6}$ ). Thus, the overall rate of growth of juveniles at TRACRS was intermediate between those of juveniles living in their natural habitats.

\subsection{Density effects on growth rate}

Initial (previous autumn) biomass densities in separate pens ranged from a low of $0.27 \mathrm{~g}$ tortoise $\mathrm{m}^{-2}$ in 2006 to a high of $18.10 \mathrm{~g} \mathrm{~m}^{-2}$ in 2016 . The only significant relationships between annual growth rate and initial juvenile biomass density were negative relationships that occurred during 4 rainfall years (2010, 2011, 2013, and 2014). We hypothesized that any year having a substantial food shortage should show a downward deflection in growth rate at high biodensities, beyond the point where food supply exceeds food demand. However, the results do not support this hypothesis; there was no clear deflection point or threshold (Fig. 8). Growth rates during 2013 were unusually low (also see Table S1).

\subsection{BCI and SHI}

The mean autumn BCIs ranged from 0.48-0.58 g body mass $\mathrm{cm}^{-3}$. There were 2 instances where mean BCI values were slightly below 0.45 , indicating very 


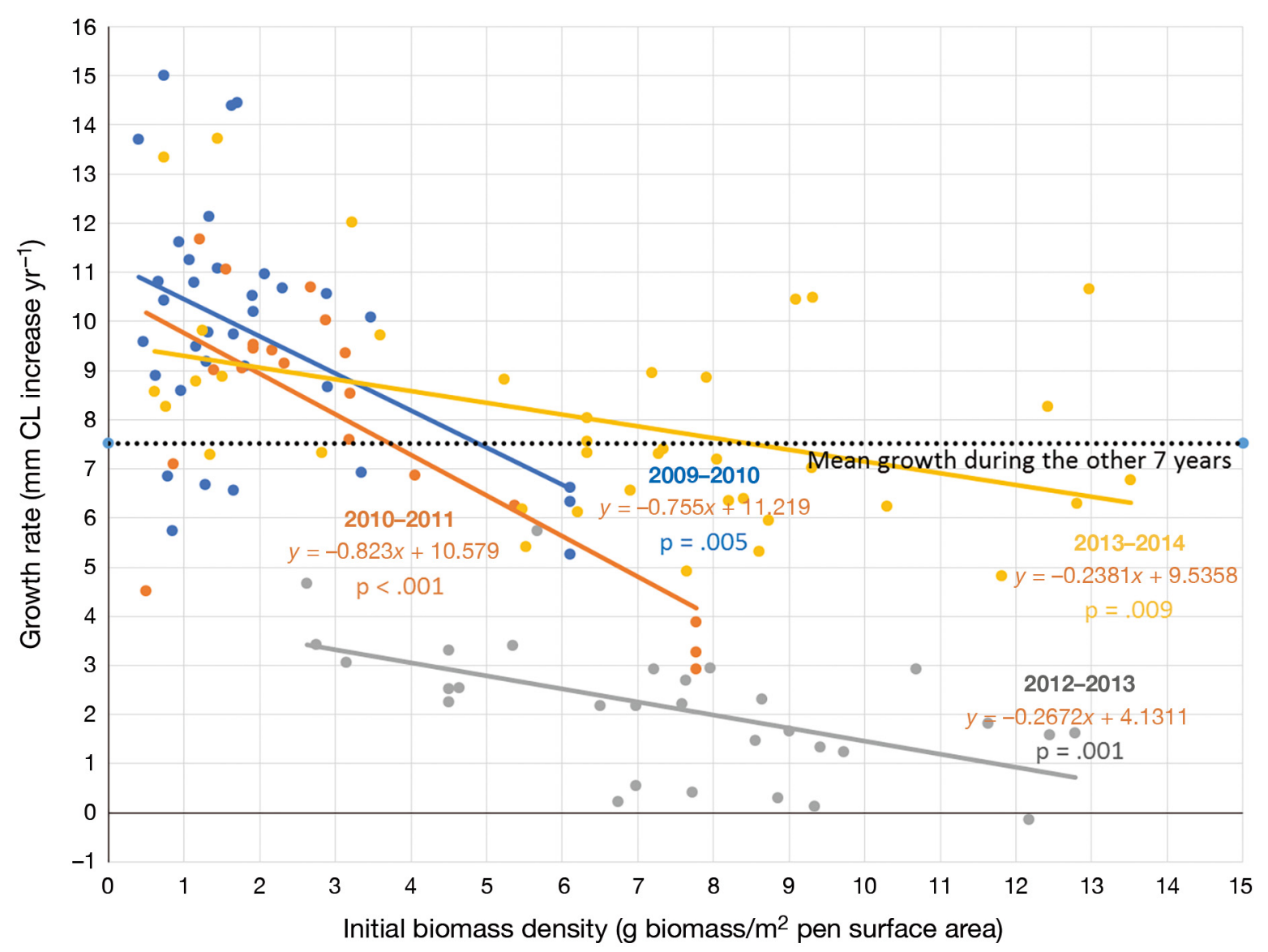

Fig. 8. Relationships of Agassiz's desert tortoise annual growth rates to tortoise biomass densities in 4 different years. Each point represents mean annual growth rate of all juveniles living in a given pen and the tortoise biomass density in that pen at the beginning of that rainfall year. Different colors represent different rainfall years. Data and associated linear regression lines are shown only for the 4 years having significant effects of biomass density on growth (all $F>7.61$, adjusted $\mathrm{r}^{2}>0.152, \mathrm{p} \leq$ $0.009, \mathrm{n}>18$ ); all 4 years had below average rainfall. Growth rates during 2012-2013 were unusually low at all biomass densities, and several groups of tortoises had growth rates near or below zero that year

mild dehydration. One was the 2006 cohort in year 2008 (0.44), and the other being the 2008 cohort (0.44) in 2010, both during years when precipitation and irrigation were low. However, during the drought year of 2010, the average BCI of all juveniles was higher, at 0.50 .

As juvenile CL (in $\mathrm{mm}$ ) increased, SHI increased asymptotically toward adult SHI (i.e. 100\%; Fig. S1). The transform of SHI $(\ln [100-\mathrm{SHI}])$ was linearly correlated with CL $\left(F_{1,626}=2841, \mathrm{p}<10^{-5}, \mathrm{r}^{2}=0.82\right)$, with the regression equation $\ln (100-\mathrm{SHI})=4.489-$ $(0.0325 \times \mathrm{CL})$. Similarly, the relationship between SHI and age (in years) was significant $\left(F_{1,626}=2605\right.$, $\left.\mathrm{p}<10^{-4}, \mathrm{r}^{2}=0.81\right)$, with an equation of $\ln (100-\mathrm{SHI})=$ $3.107-(0.238 \times$ age $)$. The relationships of shell hardness (ln[100 - SHI]) to size (CL) for irrigated (this study) and unirrigated (from Nagy et al. 2011) head-started tortoises had similar slopes (ANCOVA, $\left.t_{665}=1.01, \mathrm{p}>0.15\right)$ but different elevations (ANCOVA, $t_{665}=-5.55, \mathrm{p}<10^{-6}$ ). The unirrigated tortoises had the lower curve $(\ln [100-\mathrm{SHI}]=4.039$ $-[0.0323 \times \mathrm{CL}])$, indicating that their shell hardened at a smaller size than did shells of irrigated tortoises $(\ln [100-\mathrm{SHI}]=4.479-[0.0323 \times \mathrm{CL}]) ;$ at the same $\mathrm{CL}$, irrigated tortoises had softer shells than did unirrigated tortoises (Table 4). The slopes of shell hardness-to-age relationships (log-linear) differed between irrigated and unirrigated juveniles $\left(t_{665}=\right.$ $4.436, \mathrm{p}<0.00001)$. The slope for the irrigated tortoise equation $(\ln [100-\mathrm{SHI}]=3.107-0.238 \times$ age; $\left.F_{1,626}=2605, \mathrm{p}<0.001, \mathrm{r}^{2}=0.81\right)$ was steeper than that for unirrigated tortoises $(\ln [100-\mathrm{SHI}]=2.941-$ $0.1946 \times$ age $\left.F_{1,39}=271, \mathrm{p}<0.001, \mathrm{r}^{2}=0.87\right)$. Above $7.3 \mathrm{yr}$ of age (Zerbe test, $\mathrm{p}<0.05$ ), irrigated tortoises had significantly harder shells than did unirrigated tortoises. Additionally, we calculated the expected 
Table 4. Carapace length (CL; $\mathrm{mm})$ and age (yr) at which irrigated (this study, $\mathrm{n}=628$ ) and unirrigated (Nagy et al. 2011, $\mathrm{n}=41$ ) juvenile Agassiz's desert tortoises attained shell hardness values of 98 and $99 \%$ of adult shell hardness. Juveniles were 1-12 yr old (irrigated) and 2-16 yr old (not irrigated)

\begin{tabular}{|c|c|c|c|c|}
\hline \multirow{2}{*}{$\begin{array}{l}\text { Shell hardness } \\
\text { index }\end{array}$} & \multicolumn{2}{|c|}{$-\mathrm{CL}-$} & \multicolumn{2}{|c|}{ — Age } \\
\hline & $98 \%$ & $99 \%$ & $98 \%$ & $99 \%$ \\
\hline Not irrigated & 104 & 125 & 11.6 & 15.1 \\
\hline Irrigated & 117 & 139 & 10.1 & 13.1 \\
\hline
\end{tabular}

ages when unirrigated and irrigated juveniles reached 98 and $99 \%$ of adult SHI (Table 4). Shells of irrigated juveniles hardened $1.5 \mathrm{yr}$ faster and at a larger size (12\% larger) than did shells of unirrigated tortoises.

\section{DISCUSSION}

\subsection{Survivorship}

We demonstrated the ability of head-starting to substantially enhance tortoise nest and egg success and to increase juvenile survival compared to the wild. Consequently, head-starting can potentially augment Agassiz's desert tortoise Gopherus agassizii populations and species recovery (USFWS 2011a) by providing releasable, healthy juveniles that are past their highest mortality stages.

In natural habitats, emergence success (percent of emerging neonates per 100 eggs laid) was 55.2\% (at Goffs; Turner et al. 1987a) and 68.9\% (in Sand Hill, $<5 \mathrm{~km}$ from TRACRS; Bjurlin \& Bissonette 2004). These 2 studies documented substantial nest predation by vertebrates $(37 \%$ at Goffs and $26 \%$ at Sand Hill). At Goffs, egg and nest mortality were attributed to (1) infertile eggs $(6.1 \%)$, (2) broken eggs $(6.6 \%)$, and (3) nest predation $(32.1 \%$; Turner et al. 1987a). At TRACRS, we observed no signs of vertebrate predation on nests, and emergence success was relatively high (73.8\% over $8 \mathrm{yr}$; Table 2$)$, but was not as high as expected from Goffs results in the absence of predation $(87.3 \%)$. It is possible that non-vertebrate organisms, such as subterranean invertebrates, fungus, or microbe infections reduced emergence success at TRACRS, or there may be spatio-temporal variation in nest and emergence success. In another head-start study (Nagy et al. 2015a), native fire ants swarmed, killed, and consumed 30\% of neonate tortoises underground while hatchlings emerged from nests; subsequent predator control measures were effective.

After $9 \mathrm{yr}$, the first cohort hatched at TRACRS (2006) had 42 live juveniles per 100 eggs laid. This is 6.6 times the expected number of $9 \mathrm{yr}$ old juveniles (7.3 per 100 eggs) surviving in a wild population (from Goffs life table analysis; Turner et al. 1987a). After $11 \mathrm{yr}$, the 2006 cohort had 37 live juveniles, which is 7.3 times the life table expectation of 5.06 alive, had those eggs been laid in the field. Improvements in TRACRS structure, maintenance, and husbandry over time have increased annual survival, such that the expected 11 yr survival from 100 eggs, calculated using annual means of cohort survival (Table 2, bottom row), is 51 juveniles (Fig. 9). This is 10 times the survival of 5.06 per 100 eggs expected in the wild (Goffs; Turner et al. 1987a).

The current survivorship of wild tortoises, especially neonates and small juveniles, may be much lower than in earlier studies of remote wild populations (i.e. Turner et al. 1987a). The recent density decline (50\% from 2005-2014; USFWS 2015) in wild adult $G$. agassizii has pushed many populations near or below thresholds of viable population densities (USFWS 1994, USMC 2017, Berry \& Murphy 2019). MCAGCC populations have experienced comparable declines over the past few decades (USMC 2017). The proportion of juveniles in wild populations also appears to have declined since 2007 (Allison \&

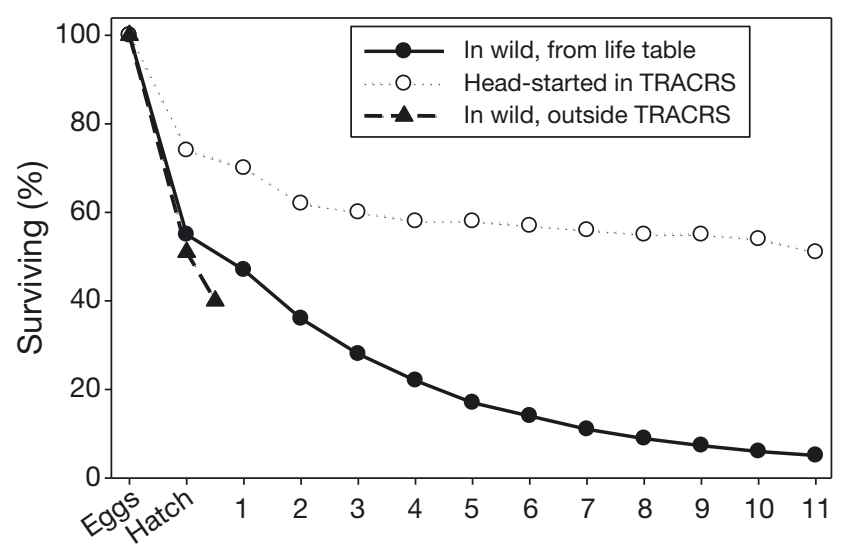

Phases of life: egg, hatchling, juvenile (years of age)

Fig. 9. Survivorship curves for Agassiz's desert tortoises, Gopherus agassizii, while free-living and while being headstarted in field enclosures (as calculated using consecutive, mean annual survivorship values in Table 2). At $11 \mathrm{yr}$ old, $51 \%$ of head-start (this study) and $5.06 \%$ of wild (filled circles, Goffs study site; Turner et al. 1987a) offspring would survive. Nest predation in the wild near TRACRS (Bjurlin \& Bissonette 2004; triangles) was similar to that at Goffs (Turner et al. 1987a), and ensuing pre-brumation predation was high 
McLuckie 2018). This may be due largely to increased populations of, and prey switching by, subsidized predators (e.g. common ravens Corvus corax and coyotes Canis latrans; Esque et al. 2010, Berry et al. 2013), but their survival may also be affected by factors that can reduce fecundity (e.g. food availability; Turner et al. 1986, 1987a, Henen 1993, 1997 , Lovich et al. 2015) and slow juvenile growth, among other causes. Consequently, head-starting may be central to bolstering the declining natural populations of Agassiz's desert tortoises. However, biologists have expressed concern about post-release survival (e.g. Heppell et al. 1996, Siegel \& Dodd 2000, Reed et al. 2009), with models suggesting that headstarting cannot, logistically and numerically, augment and sustain populations. We anticipate measuring survival rates of released head-started TRACRS juveniles in an effort to evaluate these uncertainties.

\subsection{Mortality inside enclosures}

Besides preventing deaths by large predators, dehydration, and starvation, we reduced juvenile deaths several other ways. We eliminated detectable nest predation by ground squirrels by constructing fences with bands of slippery metal sheeting that rodents could not climb (Nagy et al. 2015a). Native fire ants Solenopsis xyloni were living inside enclosures in low (non-predatory) densities. When ant nests increased in size or number (e.g. after considerable rain or irrigation in spring), we reduced ant densities by placing fire ant-specific toxic bait (with Hydramethylnon) inside tortoise-excluding stations, near ant nests. By removing the ground-level bars in Enclosure 4, we reduced trapping and overturning of tortoises, greatly reducing mortality due to exposure. Frequent monitoring and repair of the bird netting in all enclosures has apparently excluded predatory birds and eliminated associated juvenile deaths. Use of aseptic handling methods through 2017 contributed to the absence of clinical signs of mycoplasmosis in head-started tortoises.

\subsection{BCI and SHI}

BCI measurements on TRACRS juveniles indicated adequate-to-good hydration and gut fill (Nagy et al. 2002) during spring and fall, especially after 2013 when we began irrigating enclosures more often through winter and spring. Those drinking opportunities supported subsequent food consumption and digestion, especially in late spring and autumn when only dry plants were available, and facilitated sustaining near-normal body mass. In contrast, free-living adult and juvenile desert tortoises typically transition from high spring BCI to reduced BCI in summer (normally a dry season; Nagy \& Medica 1986, Nagy et al. 2002), and BCI remains low into autumn if there are no drinking opportunities. Summer rains support drinking, the ensuing food consumption and increases in body and lipid mass (Henen 1997, Henen et al. 1998). In another headstart study, juveniles without irrigation developed BCI lower than 0.40 and all died during a prolonged drought of 1.33 yr (Nagy et al. 2015a). By irrigating every summer, we ensured TRACRS juveniles had opportunities to drink, eat, and hopefully grow despite the frequent drought years. Mortality among free-living adults also increases during droughts (up to $40 \%$ dying $\mathrm{yr}^{-1}$; Turner et al. 1984, Peterson 1994, Longshore et al. 2003, Field et al. 2007, Lovich et al. 2014, Berry \& Murphy 2019). Juvenile mortality should also increase in droughts and be higher than adult rates, especially given juveniles' small size, high surface-to-volume ratios, and high mass-specific metabolic rates (Nagy et al. 1997). Yet annual mortality rates for our head-start juveniles were $<17 \%$ during the 2007-2010 drought (excluding the 2010 avian mortality event in the 2009 cohort; Table 2) and $<8 \%$ in almost every cohort every year of the 2012-2016 drought (the 2013 cohort in 2014 was the exception). We irrigated more during the latter drought than in the prior drought. Thus, head-starting protected juvenile tortoises from death by dehydration, starvation, and predation.

The SHI of irrigated juveniles increased faster than in juveniles head-started without irrigation (Nagy et al. 2011). Moreover, juveniles with irrigation also reached adult shell hardness at a larger size. Both of these benefits reduce head-starting duration and costs by allowing earlier releases and increased defenses to raven predation.

\subsection{Growth rates}

Despite irrigating to counter drought conditions (i.e. to hydrate tortoises and promote food plant growth), our juveniles' overall growth was not higher than average rates in wild juvenile tortoises but was comparable to rates in other irrigated headstart facilities (4.2-11.9 $\mathrm{mm} \mathrm{yr}^{-1}$; Nagy et al. 2015a, Nafus et al. 2017, Mack et al. 2018, Tuberville et al. 2019). 


\subsubsection{Free-living versus head-start}

Average annual growth rates of free-living juveniles in 3 natural populations were higher or lower than the average growth rate at TRACRS (Fig. 7). The growth rate differences between the 3 field populations appear positively related to variation in annual rainfall amounts: Rock Valley, $160.2 \mathrm{~mm}$ rain $\mathrm{yr}^{-1}$ (45 yr average; Medica et al. 2012); Goffs, $167.9 \mathrm{~mm}$ rain $\mathrm{yr}^{-1}$ (during $4 \mathrm{yr}$ of the study; Turner et al. 1987a); and Fort Irwin, $48.0 \mathrm{~mm}$ rain $\mathrm{yr}^{-1}$ (3 yr average from 2005-2008; Nagy et al. 2015b). But these average annual growth rates of free-living juveniles include both high-rainfall years with much food available, and low (or no) rainfall years when herbs are absent. During 'good' rainfall years, wild juveniles can grow up to twice as fast as the average rate (Medica et al. 2012, L. S. Hillard \& K. A. Nagy unpubl. data). At TRACRS, we tried to achieve a 'good' herbaceous production year every year by irrigating. So why did TRACRS juveniles not achieve higher growth rates? To address this, we examined the relationships between growth, total precipitation (rain plus irrigation), food availability, and tortoise biomass density.

\subsubsection{Precipitation and food availability}

Growth responses to precipitation (rainfall and irrigation) and food supply are essential to an understanding of the effectiveness of head-starting efforts and general tortoise biology. Although these responses are complicated or obscured by the large variation in growth rates (Table S1), the large individual variation is consistent with results from numerous studies of desert tortoise growth (e.g. Nagy \& Medica 1986, Turner et al. 1987b, Medica et al. 2012), physiology (Nagy \& Medica 1986, Peterson 1996, Henen 1997, Henen et al. 1998, Drake et al. 2012, Nafus et al. 2017, among others), and behavior (Woodbury \& Hardy 1948, Medica et al. 1980, Nagy \& Medica 1986, Nafus et al. 2017, among others). Such large variation may appear extreme, but it is likely exaptive for desert reptiles (Bradshaw 1988, 1997) and other ectotherms (Pough 1980), and central to their species' success in arid environments.

Nonetheless, the growth rates here correlated strongly with plant cover (an indicator of food supply) and correlated mildly with precipitation. Precipitation influences plant production in complex ways (e.g. Beatley 1974, Turner \& Randall 1989), and young herbaceous plants are the primary food source as tortoises emerge from winter dormancy (Nagy \& Medica 1986, Henen 1993, 2002, Lovich et al. 2015, and many others). We expected tortoise growth rates to be related less to total annual precipitation, as the sum of rainfall and irrigation, than to plant cover, because the effects of precipitation timing and amounts on plant germination and growth vary considerably. Food plants also provide more than water to tortoises (Nagy \& Medica 1986, Henen 1997), with egg production asymptotically related to the availability of annual plants (an indicator of plant production whether annual or perennial; Turner et al. 1987a, Henen 1993, 1997, Lovich et al. 2015). At TRACRS, late fall and early winter precipitation $>15 \mathrm{~mm}$ could initiate germination of herbs but if little or no precipitation occurred by mid-February, germination was minimal despite subsequent irrigation (e.g. in 2012-2013; Fig. 10). Late spring precipitation sustained plant growth to May or June. Summer precipitation had little effect on winter herbs that survived through spring.

As our tortoises grew and their body mass increased, they ate more of their preferred plant foods early in the year, before the plants could flower, set seed, and add these seeds to the soil seed bank. Consequently, plant species richness declined (especially in 2011-2012; Fig. 10), and the remaining plants were of low feeding preference or were non-native species. It was necessary to provide nursery-grown plants for food in springs of 2007, 2012, and 2013 and

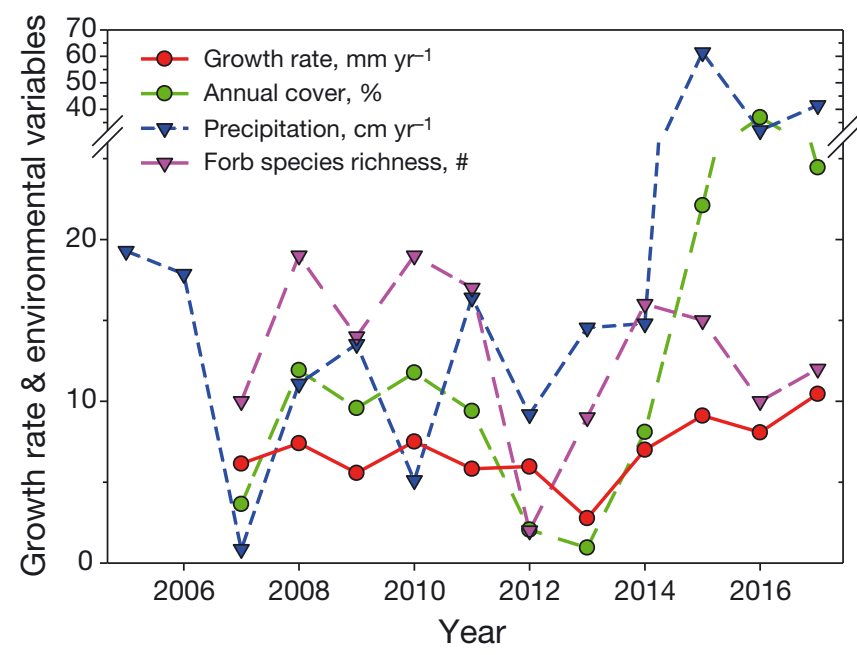

Fig. 10. Annual growth rates of juvenile Agassiz's desert tortoises ( $\mathrm{mm} \mathrm{yr}^{-1}$ increase in carapace length), indices of natural plant food supply (\% of ground covered by resident annual plants, excluding imported food supplements added in 2007 and 2012-2017) and water supply ( $\mathrm{cm} \mathrm{yr}^{-1}$ of rainfall + irrigation), and species richness of resident forbs (no. species per $1423 \mathrm{~m}^{2}$ ) inside the TRACRS head-start enclosures 
to sow native wildflower seeds every fall beginning in 2012. Winter rainfall and irrigation in 2012-2013 was too little and too late to stimulate germination, so spring 2013 also had low plant cover, necessitating provision of more nursery plants. Beginning in 2013, we irrigated each fall immediately after seed sowing regardless of weather forecast and realized rainfall. This method increased plant cover and juvenile growth rates above those of the first $7 \mathrm{yr}$ (Fig. 10). Plant species richness also increased in response to regular irrigation and seeding. We also irrigated briefly, 30-60 min, during summer so tortoises could drink, eat the available dry plants (Nagy \& Medica 1986, Henen 1997, 2002), and eat the Bermuda grass hay which we began providing each summer starting in 2012. With these modifications in irrigation, seeding, and dry food supplementation, growth rates in TRACRS increased to levels seen in free-living juveniles during 'good' years (Medica et al. 2012).

\subsubsection{Biomass density and food supply}

If growth rates were limited just by food supply and not influenced by food quality, we would suspect that annual growth rates would be lower in pens with greater densities of tortoise biomass. However, this did not occur in 7 of the $11 \mathrm{yr}$, and in 3 of the other 4 yr (2009-2010, 2010-2011，2013-2014; Fig. 8), growth rates were near average (Table S1). Except for the very low growth rate in the year with the lowest plant cover, 2012-2013, growth rates in the other $10 \mathrm{yr}$ varied little and seemed to plateau despite increasing food availability (i.e. plant cover; Fig. 6), suggesting food availability rarely limited growth. At Edwards Air Force Base (EAFB) in 2010-2012, headstart juveniles had very low growth rates $(3.7 \mathrm{~mm}$ $\left.\mathrm{yr}^{-1}\right)$, but also had low condition indices, poor health, lethargy, and high mortalities despite some irrigation (Mack et al. 2018). The biomass densities at EAFB were (ca. 3-7 $\mathrm{g} \mathrm{m}^{-2}$; calculated from Mack et al. 2018) intermediate to those at TRACRS (Fig. 8). Herbaceous plants available at EAFB's facility, composed primarily of 3 non-native annual grasses of low nutritional quality (Hazard et al. 2009, 2010), support Mack et al.'s (2018) suggestion that EAFB pens lacked sufficient mass of preferred herbs to sustain the animals. Hatchling desert tortoises grew at high rates (9.6-11.9 $\mathrm{mm} \mathrm{yr}^{-1}$; Nafus et al. 2017) at an irrigation-equipped head-start facility that had a plant population with good native species richness and cover. There, first-year juveniles also showed maternal effects on growth rates, with larger mothers pro- ducing larger hatchlings that grew faster and had higher survivorship (Nafus et al. 2015).

Head-start overcrowding may limit juvenile growth inside head-start facilities via more than one means. Although maximum biodensities inside TRACRS (12-13 $\mathrm{g} \mathrm{m}^{-2}$; Fig. 8) were more than 100 times that of wild adults in the surrounding habitat $\left(0.097 \mathrm{~g} \mathrm{~m}^{-2}\right.$, assuming $1002.5 \mathrm{~kg}$ adults $\mathrm{mi}^{-2}$ or $38.62 .5 \mathrm{~kg}$ adults $\mathrm{km}^{-2}$; Woodman et al. 2001), growth rates inside TRACRS were low in only 1 of $11 \mathrm{yr}$, and that was during the most severe food paucity (Fig. 8). Consequently, extreme food shortage and food composition (e.g. low availability of preferred forbs and grasses) provides one estimate of maximum biodensity in head-start enclosures.

Qualitatively, we detected early seasonal reductions of specific food plant species as juveniles emerged from winter brumation. We suspect they consumed their 'preferred' foods as seedlings, before those plants could grow, provide a larger source of food, and set seed that sustains the seed bank. Additionally, the remaining 'less-preferred' plant species would be consumed less vigorously, subsequently propagating and competing with preferred species. Wild juveniles have much lower constraint on movements, so wild juveniles should have access to much greater areas to forage selectively on more nutritious foods.

In order to be of a manageable size and yet produce useful numbers of large juveniles for release, head-start facilities can have biomass density constraints that reduce food plant diversity, food plant productivity, and soil seed banks. We countered these reductions by sowing seeds of preferred food plants in autumn and early winter and irrigating deeply and regularly after sowing through the ensuing May. Additionally, we controlled some seedeaters (ants and rodents) but not small birds that easily ingressed through cyclone fencing and overhead nets.

\section{RECOMMENDATIONS}

The recommendations below are based primarily on results in this study, located in the south-central part of the Mojave Desert. Rainfall patterns and average annual precipitation amounts vary widely across the species' range, from relatively high winter rainfall in the western areas to low, mostly winter rainfall in the central Mojave area, and relatively high summer rainfall in eastern parts of the range. Similarly, the species composition of tortoise food plants varies from mainly winter annuals in the west to a mixture 
of winter and summer annuals in the east (see Henen 1997, Wallis et al. 1999, and references therein). We suggest that the recommendations below, which are based on results from a relatively low rainfall area with mainly winter rainfall, be applied considering regional differences in climate. In hindsight, some of these recommendations may now seem obvious, but our initial research strategy was to start with a protocol that was current, low-cost, and simple to operate, but with the caveat to adaptively manage with more intensive procedures as our results indicated necessary for successful head-starting.

(1) To help sustain soil seed banks in head-start enclosures, seeds of preferred plant species should be sown in autumn (October and November) of each year.

(2) After sowing seeds, irrigation should commence in October or November, as desert rainfall is, and forecasts are, extremely variable and unpredictable (Louw \& Seely 1982, this study).

(3) Tortoises were more apt to remain above ground, eat, and grow if they were hydrated (Nagy et al. 2015a). To provide drinking water, we recommend irrigating for at least $30 \mathrm{~min}$ as juveniles emerge from brumation in March, several times in spring (especially during droughts), in early June before summer heat arrives, and in late August and September to enable drinking and eating before brumation. Dehydrated tortoises may emerge in winter rains to drink, and subsequently they may be prone to die from sudden cold exposure (B. Henen \& Mark Bratton independent obs.).

(4) Irrigation should continue about biweekly during spring (in the south-central region of the Mojave Desert) to sustain food plant growth, extend tortoise foraging on these plants, and foster production of food plant seeds.

(5) Bermuda grass hay can be provided in dry months (ca. 1 June to 15 October) if dead forb and grass plant matter is sparse, as hydrated juveniles (like adults; Henen 1997) continue eating during summer.

(6) Herbaceous plant growth should be monitored in enclosures to obviate or mitigate overgrazing, early senescence (e.g. in droughts), and loss of species diversity.

(7) If new plants fail to germinate by February or March, add, irrigate, and resupply nursery-grown plants (e.g. Gazania spp. and grass sod) as a continuous fresh food supply through May.

(8) Head-start enclosures should avoid use of horizontal bars or beams inside near ground level as they contribute to overturning, overheating, and death.
(9) The bird netting overhead must be inspected frequently to discover and repair degradation and damage caused by sunlight, strong winds, heat, and gnawing rodents that enables bird depredation of juveniles.

(10) Avoid overstocking tortoises (e.g. biomass density > 5 $\mathrm{g} \mathrm{m}^{-2}$ ), which compromises tortoise growth, health, and survival (especially during droughts) during conditions of low food diversity, quality, and abundance.

Acknowledgements. This research was funded by the US Marine Corps, Environmental Affairs Division at MCAGCC, via US Army Research Office Grants W911NF-05-1-0220 and US Navy Cooperative Agreements (through Naval Facilities Engineering Command [Atlantic Division: N62470-12-2-7013 and Southwest Division: N62470-12-27013 \& N62473-17-2-0015]). We are grateful for planning, logistic, and funding support from MCAGCC (LtCol J. Aytes, M. Cottrell, R.M. Evans, M.B. Husung, N.A. Hotch, S. Selser and R. Garcia) and the US Navy (Chris Peterson and Aaron Hebshi), Mary Brown for Mycoplasma sp. antibody tests, Michael Tuma for unpublished FISS data, Rasoul Sharifi for seed tests of soils, Barry Prigge for plant identifications, Christiane Weise, Brian Kot, Charles Peterson, Margaret Adam, Patricia Nagy, Randy Overbeck, and Boy Scout Troop 34 for help in the field, Crystal Johnson for data analyses, Reggie Garcia and his MCAGCC Roads and Grounds Crew for water deliveries, Salvatore and Mary Lou Sortino for logistical support, Clarence Everly and Dave Houseman for historical weather data for Fort Irwin, and Roy Averill-Murray and Rebecca Jones for permit advice. This research followed ASIH-SSAR Guidelines (Beaupre et al. 2004), and permits from the US Fish and Wildlife Service (TE-085050), the California Department of Fish and Wildlife (Scientific Collecting Permit SC001954), and the UCLA Animal Research Committee (ARC 1992-057).

\section{LITERATURE CITED}

Allison LJ, McLuckie AM (2018) Population trends in Mojave desert tortoises (Gopherus agassizii). Herpetol Conserv Biol 13:433-452

Barrows CW, Henen BT, Karl AE (2016) Identifying climate refugia: a framework to inform conservation strategies for Agassiz's desert tortoise in a warmer future. Chelonian Conserv Biol 15:2-11

Beatley JC (1974) Phenological events and their environmental triggers in Mojave Desert ecosystems. Ecology 55:856-863

Beaupre SJ, Jacobson ER, Lillywhite HB, Zamudio K (2004) Guidelines for use of live amphibians and reptiles in field and laboratory research. American Society of Ichthyologists and Herpetologists. https://asih.org/sites/default/ files/documents/resources/guidelinesherpsresearch2004. pdf

Berry KH, Murphy RW (2019) Gopherus agassizii (Cooper 1861)—Mojave desert tortoise, Agassiz's desert tortoise. In: Rhodin AGJ, Iverson JB, van Dijk PP, Stanford CB and others (eds) Conservation biology of freshwater turtles and tortoises: a compilation project of the IUCN/SSC 
tortoise and freshwater turtle specialist group. Chelonian Research Monographs No. 5. Chelonian Research Foundation and Turtle Conservancy, Lunenburg, MA

Berry KH, Yee JL, Coble AA, Perry WM, Shields TA (2013) Multiple factors affect a population of Agassiz's desert tortoise (Gopherus agassizii) in the northwestern Mojave Desert. Herpetol Monogr 27:87-109

Bjurlin CD, Bissonette JA (2004) Survival during early life stages of the desert tortoise (Gopherus agassizii) in the south-central Mojave Desert. J Herpetol 38:527-535

Bradshaw SD (1988) Desert reptiles: A case of adaptation or pre-adaptation? J Arid Environ 14:155-174

Bradshaw SD (1997) Homeostasis in desert reptiles. SpringerVerlag, Berlin

Brown MB, Berry KH, Schumacher IM, Nagy KA, Christopher MM, Klein PA (1999) Seroepidemiology of upper respiratory tract disease in the desert tortoise in the Western Mojave Desert of California. J Wildl Dis 35:716-727

Christopher MM, Berry KH, Wallis IR, Nagy KA, Henen BT, Peterson CC (1999) Reference intervals and physiologic alterations in hematologic and biochemical values of freeranging desert tortoises in the Mojave Desert. J Wildl Dis 35:212-238

*hristopher MM, Berry KH, Henen BT, Nagy KA (2003) Clinical disease and laboratory abnormalities in freeranging desert tortoises in California (1990-1995). J Wildl Dis 39:35-56

Congdon JD, Gibbons JW (1990) The evolution of turtle life histories. In: Gibbons JW (ed) The life history and ecology of the slider turtle. Smithsonian Institution Press, Washington, DC, p 45-54

* Curtin AJ, Zug GR, Spotila JR (2009) Longevity and growth strategies of the desert tortoise (Gopherus agassizii) in two American deserts. J Arid Environ 73:463-471

* Drake KK, Nussear KE, Esque TC, Barber AM and others (2012) Does translocation influence physiological stress in the desert tortoise? Anim Conserv 15:560-570

Esque TC, Nussear KE, Drake KK, Walde AD and others (2010) Effects of subsidized predators, resource variability, and human population density on desert tortoise populations in the Mojave Desert, USA. Endang Species Res 12:167-177

Field KJ, Tracy CR, Medica PA, Marlow RW, Corn PS (2007) Return to the wild: translocation as a tool in conservation of the desert tortoise (Gopherus agassizii). Biol Conserv 136:232-245

Germano DJ (1994) Growth and age at maturity of North American tortoises in relation to regional climates. Can J Zool 72:918-931

Gibbons JW, Greene JL (1979) X-ray photography: a technique to determine reproductive patterns of freshwater turtles. Herpetologica 35:86-89

Hazard LC, Shemanski DR, Nagy KA (2009) Nutritional quality of natural foods of juvenile desert tortoises (Gopherus agassizii): energy, nitrogen, and fiber digestibility. J Herpetol 43:38-48

Hazard LC, Shemanski DR, Nagy KA (2010) Nutritional quality of natural foods of juvenile and adult desert tortoises (Gopherus agassizii): calcium, phosphorus and magnesium digestibility. J Herpetol 44:135-147

Henen BT (1993) Desert tortoise diet and dietary deficiencies limiting tortoise egg production at Goffs, California. In: Beaman KR (ed) Proc $17^{\text {th }}$ Annu Desert Tortoise Council Symp, Las Vegas, NV. Desert Tortoise Council, Palm Desert, CA, p 97
Henen BT (1997) Seasonal and annual energy budgets of female desert tortoises, Gopherus agassizii. Ecology 78: 283-296

Henen BT (2002) Reproductive effort and reproductive nutrition of female desert tortoises: essential field methods. Integr Comp Biol 42:43-50

* Henen BT, Peterson CC, Wallis IR, Berry KH, Nagy KA (1998) Effects of climatic variation on field metabolism and water relations of desert tortoises. Oecologia 117: 365-373

Heppell SS, Crowder LB, Crouse DT (1996) Models to evaluate headstarting as a management tool for long-lived turtles. Ecol Appl 6:556-565

Jacobson ER, Weinstein M, Berry K, Hardenbrook C, Tomlinson KC, Freitas D (1993) Problems with using weight versus carapace length relationships to assess tortoise health. Vet Rec 132:222-223

Karl AE (1999) Reproductive strategies, growth patterns, and survivorship of a long-lived herbivore inhabiting a temporally variable environment. PhD dissertation, University of California, Davis, CA

Kuchling G (1999) The reproductive biology of the Chelonia. Springer-Verlag, Berlin

Loehr VJT, Henen BT, Hofmeyr MD (2006) Shell characteristics and sexual dimorphism in the Namaqualand speckled padloper, Homopus signatus. Afr J Herpetol 55: $1-11$

* Longshore KM, Jaeger JR, Sappington JM (2003) Desert tortoise (Gopherus agassizii) survival at two eastern Mojave Desert sites: Death by short-term drought? J Herpetol 37 : 169-177

Louw GN, Seely MK (1982) Ecology of desert organisms. Longman, New York, NY

* Lovich JE, Yackulic CB, Freilich J, Agha M and others (2014) Climatic variation and tortoise survival: Has a desert species met its match? Biol Conserv 169:214-224

* Lovich JE, Ennen JR, Yackulic CB, Meyer-Wilkins K and others (2015) Not putting all their eggs in one basket: bet-hedging despite extraordinary annual productive output of desert tortoises. Biol J Linn Soc 115:399-410

* Mack JS, Schneider HE, Berry KH (2018) Crowding affects health, growth, and behavior in headstart pens for Agassiz's desert tortoise. Chelonian Conserv Biol 17:14-26

McGovern PA (2019) Changing the survival formula for the Mojave desert tortoise (Gopherus agassizii) through head-starting. MS thesis, University of Georgia, Athens, GA

Medica PA, Bury RB, Luckenbach RA (1980) Drinking and construction of water catchments by the desert tortoise, Gopherus agassizii, in the Mojave Desert. Herpetologica 36:301-304

Medica PA, Nussear KE, Esque TC, Saethre MB (2012) Long-term growth of desert tortoises (Gopherus agassizii) in a Southern Nevada population. J Herpetol 46: 213-220

Morafka DJ (1994) Neonates: missing links in the life histories of North American tortoises. In: Bury RB, Germano DJ (eds) Biology of North American tortoises. Fish and Wildlife Research No. 13. US Department of the Interior, National Biological Survey, Washington, DC, p 161-173

Morafka DJ, Berry KH, Spangenberg EK (1997) Predatorproof field enclosures for enhancing hatching success and survivorship of juvenile tortoises: a critical evaluation. In: Van Abbema J (ed) Proceedings: conservation, restoration, and management of tortoises and turtles- 
an international conference, 11-16 July 1993. New York Turtle and Tortoise Society, New York, NY, p 147-165

Mueller JM, Sharp KR, Zander KK, Rakestraw DL, Rautenstrauch KR, Lederle PE (1998) Size-specific fecundity of the desert tortoise (Gopherus agassizii). J Herpetol 32: 313-319

Nafus MG, Todd BD, Buhlmann KA, Tuberville TD (2015) Consequences of maternal effects on offspring size, growth and survival in the desert tortoise. J Zool (Lond) 297:108-114

Nafus MG, Tuberville TD, Buhlmann KA, Todd BT (2017) Precipitation quantity and timing affect native plant production and growth of a key herbivore, the desert tortoise, in the Mojave Desert. Clim Change Responses 4: $4-10$

Nagy KA, Medica PA (1986) Physiological ecology of desert tortoises in southern Nevada. Herpetologica 42:73-92

Nagy KA, Morafka DJ, Yates RA (1997) Young desert tortoise survival: energy, water and food requirements in the field. Chelonian Conserv Biol 2:396-404

Nagy KA, Henen BT, Vyas DB, Wallis IR (2002) A condition index for the desert tortoise (Gopherus agassizii). Chelonian Conserv Biol 4:425-429

Nagy KA, Tuma MW, Hillard LS (2011) Shell hardness measurement in juvenile desert tortoises, Gopherus agassizii. Herpetol Rev 42:191-195

Nagy KA, Hillard S, Dickson S, Morafka DJ (2015a) Effects of artificial rain on survivorship, body condition, and growth of head-started desert tortoises (Gopherus agassizii) released to the open desert. Herpetol Conserv Biol 10:535-549

Nagy KA, Hillard LS, Tuma MW, Morafka DJ (2015b) Headstarted desert tortoise (Gopherus agassizii): movements, survivorship and mortality causes following their release. Herpetol Conserv Biol 10:203-215

Nagy KA, Kuchling G, Hillard LS, Henen BT (2016) Weather and sex ratios of head-started Agassiz's desert tortoise Gopherus agassizii juveniles hatched in natural habitat enclosures. Endang Species Res 30:145-155

Peterson CC (1994) Different rates and causes of high mortality in two populations of the threatened desert tortoise, Gopherus agassizii. Biol Conserv 70:101-108

Peterson CC (1996) Anhomeostasis: seasonal water and solute relations in two populations of the desert tortoise (Gopherus agassizii) during chronic drought. Physiol Zool 69:1324-1358

Pough FH (1980) The advantages of ectothermy for tetrapods. Am Nat 115:92-112

Reed JM, Fefferman N, Averill-Murray RC (2009) Vital rate sensitivity analysis as a tool for assessing management actions for the desert tortoise. Biol Conserv 142:2710-2717

Siegel RA, Dodd CK (2000) Manipulation of turtle populations: Halfway technologies or viable options? In: Klemens MW (ed) Turtle conservation. Smithsonian Institution Press, Washington, DC, p 218-238

Tuberville TD, Buhlmann KA, Sollmann R, Nafus MG, Peaden JM, Daly JA, Todd BD (2019) Effects of shortterm, outdoor head-starting on growth and survival in the Mojave desert tortoise (Gopherus agassizii). Herpetol Conserv Biol 14:171-184

Turner FB, Randall DC (1989) Net production by shrubs and

Editorial responsibility: Brendan Godley,

University of Exeter, Cornwall Campus, UK winter annuals in southern Nevada. J Arid Environ 17: 23-36

* Turner FB, Medica PA, Lyons CL (1984) Reproduction and survival of the desert tortoise (Scaptochelys agassizii) in Ivanpah Valley, California. Copeia 1984:811-820

Turner FB, Hayden P, Burge BL, Roberson JB (1986) Egg production by the desert tortoise (Gopherus agassizii) in California. Herpetologica 42:93-104

Turner FB, Berry KH, Randall DC, White GC (1987a) Population ecology of the desert tortoise at Goffs, California, 1983-1986. Report 87-RD-81 to Southern California Edison Company, Rosemead, CA. https://escholarship.org/ uc/item/8th2d143

* Turner FB, Medica PA, Bury RB (1987b) Age-size relationships of desert tortoises in southern Nevada. Copeia 1987:974-979

US Fish and Wildlife Service (1994) Desert tortoise (Mojave population) recovery plan. US Fish and Wildlife Service, Portland, OR

US Fish and Wildlife Service (2009) Guidelines for handling desert tortoises-Mojave population and their eggs. In: Desert tortoise (Mojave population) field manual: (Gopherus agassizii). US Fish and Wildlife Service, Sacramento, CA, p 7-1-7-12

US Fish and Wildlife Service (2011a) Revised recovery plan for the Mojave population of the desert tortoise (Gopherus agassizii). US Fish and Wildlife Service, Sacramento, CA

US Fish and Wildlife Service (2011b) Health assessment procedures for the desert tortoise (Gopherus agassizii): a handbook pertinent to translocation. Desert Tortoise Recovery Office, Reno, NV

US Fish and Wildlife Service (2015) Range-wide monitoring of the Mojave desert tortoise (Gopherus agassizii): 2013 and 2014 annual reports. Report by the Desert Tortoise Recovery Office, US Fish and Wildlife Service, Reno, NV

USMC (US Marine Corps) (2017) Final supplemental environmental impact statement for land acquisition and airspace establishment to support large-scale marine air ground task force live-fire and maneuver training. Marine Corps Air Ground Combat Center, Twentynine Palms, CA

Wallis IR, Henen BT, Nagy KA (1999) Egg size and annual egg production by female desert tortoises (Gopherus agassizii): the importance of food abundance, body size, and date of egg shelling. J Herpetol 33:394-408

Wilbur HM, Morin PJ (1988) Life history evolution in turtles. In: Gans C, Huey R (eds) Biology of the Reptilia, Vol 16b. Alan R Liss, New York, NY, p 396-447

WWoodbury AM, Hardy R (1948) Studies of the desert tortoise, Gopherus agassizii. Ecol Monogr 18:145-200

Woodman P, Goodlett G, Westermeier J (2001) Technical synthesis report for desert tortoise surveys at Marine Corps Air Ground Combat Center, Twentynine Palms, CA. Kiva Biological Consulting and Jones \& Stokes, Irvine, $\mathrm{CA}$

Zar JH (1999) Biostatistical analysis, $4^{\text {th }}$ edn. Prentice-Hall, Upper Saddle River, NJ

Z Zerbe GO, Archer PG, Banchero N, Lechner AJ (1982) On comparing regression lines with unequal slopes. Am J Physiol Regul Integr Comp Physiol 242:R178-R180

Submitted: November 1, 2019; Accepted: July 27, 2020

Proofs received from author(s): October 21, 2020 